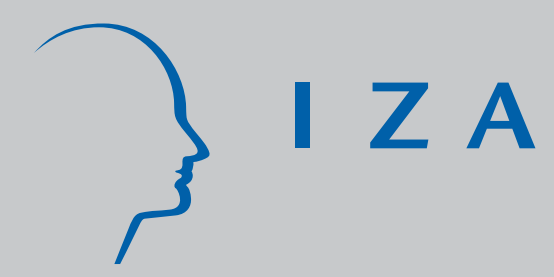

IZA DP No. 1449

Comparing Apples with Oranges:

Revisiting the Gender Wage Gap

in an International Perspective

Robert Plasman

Salimata Sissoko

December 2004 


\title{
Comparing Apples with Oranges: Revisiting the Gender Wage Gap in an International Perspective
}

\author{
Robert Plasman \\ DULBEA, Université Libre de Bruxelles \\ Salimata Sissoko \\ DULBEA, Université Libre de Bruxelles \\ and IZA Bonn
}

\section{Discussion Paper No. 1449 \\ December 2004}

\author{
IZA \\ P.O. Box 7240 \\ 53072 Bonn \\ Germany \\ Phone: +49-228-3894-0 \\ Fax: +49-228-3894-180 \\ Email: iza@iza.org
}

\begin{abstract}
Any opinions expressed here are those of the author(s) and not those of the institute. Research disseminated by IZA may include views on policy, but the institute itself takes no institutional policy positions.
\end{abstract}

The Institute for the Study of Labor (IZA) in Bonn is a local and virtual international research center and a place of communication between science, politics and business. IZA is an independent nonprofit company supported by Deutsche Post World Net. The center is associated with the University of Bonn and offers a stimulating research environment through its research networks, research support, and visitors and doctoral programs. IZA engages in (i) original and internationally competitive research in all fields of labor economics, (ii) development of policy concepts, and (iii) dissemination of research results and concepts to the interested public.

IZA Discussion Papers often represent preliminary work and are circulated to encourage discussion. Citation of such a paper should account for its provisional character. A revised version may be available directly from the author. 


\section{ABSTRACT \\ Comparing Apples with Oranges: Revisiting the Gender Wage Gap in an International Perspective*}

Using a rich and comparable micro-data set, we analyse international differences in gender pay gaps in the private sector for a sample of five European economies: Belgium, Denmark, Ireland, Italy and Spain. Using different methods, we examine how wage structure, differences in the distribution of measured characteristics, occupational and industrial segregation contribute to explain the pattern of international differences. Furthermore, we take into account indirect discrimination influencing female occupational and industrial distributions. We find significant impacts of those latter factors on gender differentials. However, the magnitude of their effects varies across countries.

JEL Classification: J16, J31, J71

Keywords: gender wage gap, wage structure, occupational segregation, industrial segregation, discrimination

Corresponding author:

Salimata Sissoko

Department of Applied Economics (DULBEA)

Université Libre de Bruxelles

CP140 - Av. F.D. Roosevelt 50

1050 Bruxelles

Belgium

Email:nsissoko@ulb.ac.be

\footnotetext{
* We thank Nabanita Datta Gupta, Jean-Luc De Meulemeester, François Rycx and Ilan Tojerow for comments and discussions on an earlier draft. This paper is produced as part of a Targeted SocioEconomic Research (TSER) project on Pay Inequalities and Economic Performance (PIEP) financed by the European Commission (Contract nr. HPSE-CT-1999-00040) and coordinated by David Marsden (London School of Economics). The data used in this study come from the 1995 European Structure of Earnings Survey. Unfortunately, due to confidentiality issues, this data set is only available for members of the PIEP research project (http://cep.Ise.ac.uk/piep/). Researchers interested in obtaining copies of the computer programs and codebooks used to generate the results should contact François Rycx.
} 
In this paper, we analyse the sources of cross-country gender wage gaps and the effects of gender labour segregation on private sector pay differentials for five European countries. Empirical research on cross-country gender wage gap is well documented in the economic literature. However, most studies focus only on the role of gender specific factors (i.e. gender differences in qualifications and labour market discrimination) and either wage structure or gender segregation (occupational and industrial). Furthermore, only few studies examine the effects of discrimination in gender segregation that remain after accounting for characteristics. Finally, the lack of rich and harmonised European micro-data set limited possibilities for European comparisons.

This paper attempts to fill this gap by addressing the three following questions: (1) What are the factors that shape European cross-country gender pay gaps? (2) What are the sizable effects of gender specific factors, wage structure and gender segregation? (3) To what extend do gender differences in personal characteristics explain the gender labour segregation and the gender pay gap?

To address these questions we use a unique harmonised European matched employeremployee data set, the 1995 European Structure of Earnings Survey, for 5 EU countries, i.e. Belgium, Denmark, Ireland, Italy and Spain. The fact that these countries present significant differences in governmental institutions has motivated our choice. This gave us the opportunity to investigate our questions on different welfare regimes: the conservative welfare model (Belgium), the Scandinavian welfare state model (Denmark), the liberal welfare state model (Ireland), the Mediterranean model (Italy and Spain).

\section{Introduction}

Abundant literature exists on the reasons that explain the gender wage differences. The first explanations come from the early 70s and are based on both Mincer and Polachek's (1974) human capital theory and on the Becker's (1971) discrimination theory.

According to Mincer and Polachek (1974) the gender wage gaps are due to endowment differences in individual characteristics. Women invest less in their own human capital because, firstly, they anticipate career breaks, which they will take throughout their working life. Secondly, women take into account the fact that their professional career could be shorter than men's because of their family responsibilities.

Becker (1971) argues that economic agents belonging to a specific group can have discriminatory preferences against members of another group. If the fact of hiring a person of a discriminated group implies an additional psychological cost for the employer, the employer will probably ask to be compensated for this and will offer a lower wage to these workers. Therefore, the discriminated group should accept a lower wage than other groups to be employed. 
The Oaxaca-Blinder (1973) decomposition technique emerges from a combination of both the above theories. The gender wage gap is, indeed, decomposed into two effects: on the one hand, the characteristic differences between men and women, and on the other hand, the discrimination against women on the labour market.

The recent literature on gender disparities has shed some light on new facts. It seems important to consider another factor: the wage structure. The latter is characterised by various determinants. One of those, maybe the most important, is the collective bargaining structure. Some authors such as Blau and Khan (1996) have shown that centralised bargaining enhances gender wage gap reduction. The main reasons are that this kind of centralisation the effect of reducing the wage differences between sectors and firms. In addition, the latter bargaining has a tendency to fix a minimum wage for all workers. In general, women are located at the lower level of the wage ladder. By reducing the wage dispersion, these systems reduce the gender wage gaps.

Juhn, Murphy and Pierce (1991, 1993) have proposed a model of wage decomposition controlling for the wage structure. This model measures the evolution of the return of the workers' (un)observed individual characteristics. According to these authors, the increasing wage inequalities in the USA can be explained by the growth of the return of (un)observed individual characteristics. Women are generally less qualified and less numerous in high pay sectors. Then, they are pushed to the bottom of the wage distribution.

The female occupational segregation also seems to influence wage differentials between genders. On the basis of the discrimination theory, Bergmann (1989) tried to explain differences in employment structure. According to this author, if women are rejected from certain male occupations, they move towards women's. Then the wage offered in these latter occupations decrease because of the labour surplus generated, even if both employments require the same level of qualifications.

Note that female employment can also require fewer qualifications and facilitate a better work/life balance. Within the theory of occupational choices, women are inclined to move towards that kind of job. An analysis in terms of indirect discrimination identifies whether the fact of offering lower wages to women working in low qualified female occupations is fair or whether it is the result of entry barriers in the best-paid and qualified occupations, and then the result of discrimination.

Brown and al. (1980) have developed a method of decomposition of the gender wage differential, which isolates the part of the gap due to differences in occupational segregation between women and men. Using a model of occupational attainment they simulate female distribution in case of non-discrimination: if their occupational attainment structure was the same as men's. Their findings show that the concentration of women in low pay occupations is not only a matter of levels of human capital.

The legislation in force on equality between men and women could also influence the inequality level. In this paper, we confront public policies on inequalities and the gender wage gap level. In particular, we show whether parental leave and child-care 
infrastructures potentially allow women to maintain a link with the labour mark and hence continue to invest in their human capital.

This study provides decompositions of the gender wage by different methods and estimates cross-country comparisons of the effect of human capital, wage structure, occupational and industrial segregation on the gender differentials.

Our findings indicate that those four factors play an important role in explaining pay differentials, although the magnitude of explanation varies across countries. A comparison between our results, the legislation on equality and institutional factors suggests that within States providing protection, generous leave benefits and public support for child-care, women are encouraged to invest more in their human capital characteristics (education, training, tenure,...), which reduce gender differences.

\section{The Data}

This study is based on the 1995 European Structure of Earnings Survey (ESES). The countries analysed are the following: Belgium, Denmark, Ireland, Italy and Spain. This survey was conducted on large representative samples for each country ${ }^{1}$. It covers establishments employing at least ten workers and with economic activities falling within $\mathrm{C}$ to $\mathrm{K}$ of the Nace Rev. 1 nomenclature.

The survey contains rich data on key micro-level variables on a comparable basis across Europe, provided by management of firms, on firm-level characteristics (e.g., sectors, level of wage bargaining, size of the establishments) as well as on individual workers (e.g. level of education, age, occupation, tenure, gender).

The dependent variable of the wage equations is the logarithm of the hourly wage (including bonus). The independent variables correspond to the employees working conditions and, worker and employee's characteristics. We have considered the number of study years, the prior potential experience (in level, squared) ${ }^{2}$, the tenure in the firm (in level and squared), the number of paid hours, the contract types, the firm size and added dummy variables for workers without tenure and for overtime.

The independent variables of the model of occupational attainment are the number of years of schooling and the potential experience and the tenure both in level and squared.

The average gender wage gap in the five European countries ${ }^{3}$ ranges from about $34 \%$ in Ireland and Spain, to $18.6 \%$ in Denmark. The gap of the other countries (Belgium and Italy) is just above the Danish one (20 and 24\% respectively).

\footnotetext{
${ }^{1}$ Size of the different data sets: Belgian sample: 145,112 individuals, Danish sample: 619,505 individuals, Irish sample: 39,105 individuals, Italian sample: 96,267 individuals, Spanish sample: 177,141 individuals

${ }^{2}$ Potential prior experience is computed as follows: age-years of schooling-start age of schooling

${ }^{3}$ Formula in national currency: $\equiv \frac{W_{h}-W_{f}}{W_{h}}$ with $W_{h}$ the average male wage and $W_{f}$ the average female wage.
} 
Table 1: Average gender wage gap in European countries, 1995

\begin{tabular}{|c|c|c|c|}
\hline \multicolumn{4}{|c|}{$\begin{array}{c}\text { Average } \\
\text { salary }\end{array}$} \\
\hline & Male & Female & Gap \\
\hline Belgium & 602.57 & 482.52 & 0.199 \\
\hline Denmark & 154.30 & 125.64 & 0.186 \\
\hline Spain & 1519.48 & 1087.20 & 0.284 \\
\hline Ireland & 10.58 & 6.97 & 0.341 \\
\hline Italy & 19.94 & 15.14 & 0.241 \\
\hline
\end{tabular}

\section{The sources of gender wage gap}

\subsection{Gender specific policies and gender wage gap}

The first specific gender directives adopted by the European Union concerns equal pay (1975) and equal treatment (1976). Since then numerous directives related to gender equality have been introduced. By promoting this principle, the European Union has become a crucial force driving the introduction and the development of gender legislation and initiatives within Members States.

Equal treatment and equal pay

Equality policies' impacts on gender wage disparities are unambiguous. However, their efficiency depends on the quality of the measures and on their application. Blau and Khan (1996) have noted that, given strong women's segregation by occupation and sector, equal pay policies, aiming at equal pay for equal work within the same occupation and sector, can only produce poor results. In contrast, measures enhancing equal opportunities and equal pay for a work of equal value, independently of the occupation, are more likely to succeed. In addition, the former type of policies asks for shifts in women's occupational structure, which may take a long time to produce any impact on pay. The latter aspires to a wage increase in female-dominated occupations and may produce a more important effect on wages.

The five European countries have all introduced laws relating to equal treatment and equal pay in their national legislation with the European Union incentives. Nevertheless, the introduction dates and the efforts devoted to reaching those equality goals vary between countries. 
Ireland and Belgium were the first countries, in our sample, to introduce equal pay in their own legislation (in 1974 and 1975 respectively). Denmark and Spain passed their equal pay acts in 1976 and Italy in 1977. Equal treatment legislation was introduced in 1977 in Italy and Belgium, in 1978 in Ireland and in 1984 in Denmark.

Each country has organised strategies to fight against gender inequalities: use of positive actions (Belgium, Spain and Italy), revisions of the occupational classification system (Belgium, Denmark and Spain), setting up of equality plans (Spain), collective bargaining (Belgium, Denmark and Ireland), legal actions (Ireland) and setting up of relevant institutions for equality in every countries.

Particularly, notice that the Belgian State has trouble to motivate social partners to reconsider the occupational classification system. Denmark is the Member State that resorts to the collective bargaining most to introduce the European Union directives into its legislation. Spain is a highly decentralised country: between 1988 and 1994, each of its 17 regions introduced its own gender equality institutions. In this way, Spanish equality policies are regional rather than national. In Ireland, legal actions are numerous although compensation is low. Ireland was late in introducing its present equality legislation. This has required the pressure of several lobby groups in order to make policy-makers aware of the gender equality problem. Finally, in Italy, the law of 1991 on equal opportunities has established advisors to equality, whose role is to act when there is collective discrimination and to oblige all employers to provide statistical information on equal treatment. The impact of this law was very low because of an inadequate budget and application arrangements. These elements were extended in 2000.

* Childcare infrastructures and parental leave arrangements

The literature shows that improvements in childcare possibilities can increase the mother's participation in the labour market. This can be explained by the fact that, on the one hand, the more childcare facilities are satisfactory, the less women stay at home, ceteris paribus (Blau and Ferber 1992). On the other hand, childcare conditions seem to have a higher influence on the women's budget constraints than on their preference to stay at home (Connelly 1992, Michalopoulos 1992, Robins \& Garfinkel 1992). Therefore, the higher the cost of childcare, the lower the employment and the paid work of women will be. The observable differential of labour market participation explains part of the gender wage gap since women have less experience and tenure than men.

However, the link between parental leave and the mother's employment and earnings is more ambiguous. On the one hand, the presence of generous provisions to enhance maternity could increase the women's attachment to the labour market (Trzcinski 1991) and their investment in human capital in the long run. On the other hand, it is recognised that prolonged leave to bring up children can limit career opportunities, which require some continuity at work. Therefore, that leave can have negative impacts on women's wages in the long run.

The European directive on maternity leave (1992) grants each woman the entitlement to paid and continuous maternity leave of 14 weeks as well as the right to return to the same 
or equivalent job. Since 1999, every parent is entitled to unpaid parental leave of 3 months as well as to return to the same or equivalent job.

Table 2: Maternity Leaves, Paternity Leaves and Parental Leaves in Europe, 2002

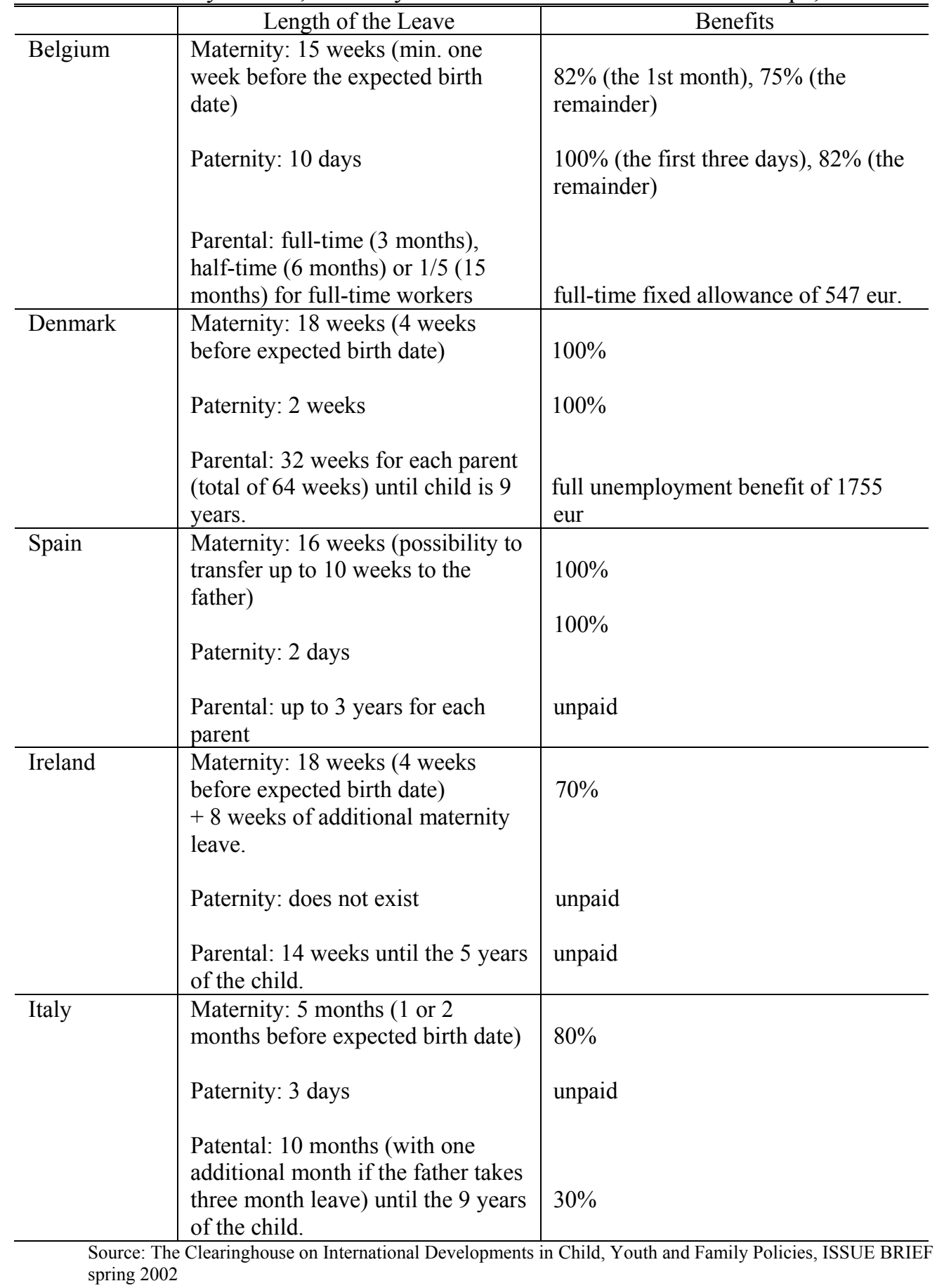

Table 1 shows that every country meets this obligation: maternity leave varies between 15 weeks (Belgium) and 5 months (Italy). The compensation levels ranges from $70 \%$ 
(Ireland) to $100 \%$ (Denmark and Spain). All countries also follow the directive related to parental leave. Only Belgium, Denmark and Italy provide a paid parental leave. The compensation is rather low in Italy (about 30\%), while the generosity of the system is far greater in Denmark and to a lesser extent in Belgium. Finally, the only two countries not having introduced a paid paternity leave are Ireland and Italy. This kind of arrangement simply does not exist in Ireland and is unpaid in Italy.

Table 3: Child-care structures, public sector, 1998

\begin{tabular}{l|c|l|c|c}
\hline \hline & $\begin{array}{c}\text { Age start } \\
\text { compulsory } \\
\text { schooling }\end{array}$ & Type of pre-primary provision & \multicolumn{2}{|c}{ Coverage of age group } \\
\cline { 3 - 5 } Belgium & 6 years & $\begin{array}{l}\text { Pre-primary from age 2.5 years, } 7 \\
\text { hours per day. }\end{array}$ & 30 & 3-6 years (\%) \\
\hline Denmark & 7 years & $\begin{array}{l}\text { Range of child care facilities from } \\
\text { age 6 months, up to 10 hours per } \\
\text { days. }\end{array}$ & 45 & $85+$ \\
\hline Spain & 6 years & $\begin{array}{l}\text { Pre-primary from age 3 years, 5 } \\
\text { hours per days }\end{array}$ & $<5$ & 84 \\
\hline Ireland & 6 years & $\begin{array}{l}\text { Pre-primary from age 3 years, 5 } \\
\text { hours per day }\end{array}$ & 2 & 55 \\
\hline Italy & 6 years & $\begin{array}{l}\text { Pre-primary from age 3 years, 5 } \\
\text { hours per days }\end{array}$ & 6 & 91 \\
\hline
\end{tabular}

Source: Rubery and al. (1998), Appendix Table 6.2

Table 2 shows that Member States take a long time to provide adequate childcare facilities. Indeed, for most countries, the childcare system is insufficient (number of available places, schedule flexibility, capacities, etc). Note that Denmark offers the most generous system. In other countries, except Belgium that provides a quite efficient system when children are 2 years old, the structures enrol children only when they are three.

Therefore, as far as equal treatment and equal pay policies are concerned, the standard is still imposed by the European Union. Member States fully satisfy the requirements relative to leaves. The situation is far less satisfactory regarding equal pay policies and childcare infrastructures.

We can now draw a parallel between gender equality policies described here above and the level of human capital of workers in the different countries ${ }^{4}$.

According to theses statistics women have a higher educational level than men's, except in Denmark. On the opposite, women present a prior potential experience and tenure level that are largely lower than men's, except for Danish women whose level of experience is slightly higher. Denmark aside, Belgium records the weakest gender differential in potential experience $(0.7$ year) and Spain the largest (2.7 years). Note that as our data set does not provide actual experience, we have only analysed potential experience. Although this measure tends to overestimate women's actual experience, this ranking is confirmed by the tenure differentials in firms. The countries with the weakest

\footnotetext{
${ }^{4}$ Tables 1 to 5 in Appendix give the descriptive statistics and results of the wage equations for each country.
} 
gender differentials are Denmark (one year), Italy (1.6 years) and Belgium (2.2 years). The gaps in Spain and Ireland are far higher.

We therefore observe that in countries combining generous parental leave systems (maternity, paternity, etc.) and well developed child-care infrastructures, women present higher levels of human capital (e.g. education, potential experience and tenure). The case of Belgium and Denmark confirm this hypothesis. In these countries, women are remunerated for this high level of human capital. This certainly contributes to reduce the gender wage gap in these countries.

\subsection{The wage structure and the gender wage gap}

Blau and Khan (1992 and 1996) have shown that the overall wage structure has an impact on the gender wage gap. These authors have found a positive correlation between the level of wage inequality in a country and the size of its gender gap. This finding is not surprising since we know that women are over-represented at the bottom of the wage distribution. A narrower distribution will reduce disparities between men and women.

The wage structure is influenced by the bargaining system. Corporatist countries present fewer wage inequalities than other countries. The reasons are first that centralised systems reduce variations between sectors and firms. In this way, these systems are more likely to decrease such disparities, ceteris paribus. Secondly, given that women's wage distribution is below that of men, centralised systems, which increase minimum wages irrespective of gender, also produce fewer disparities. Finally, the impact of specific gender policies, which aim at increasing the women's wage, could be more efficient in centralised systems.

When analysing the relationship between wage bargaining systems and the gender wage gap, one has also to take into account the extent of the bargaining system. In fact, even a centralised system would have few effects if it covered only a small number of workers. The indicators of the extent of the bargaining system used in this study are the degree of unionisation and the collective bargaining coverage. 
Table 4: Wage setting systems, 1994

\begin{tabular}{|c|c|c|c|c|c|c|}
\hline & $\begin{array}{c}\text { Union } \\
\text { density }^{\mathrm{a}}\end{array}$ & $\begin{array}{c}\text { Collective } \\
\text { bargaining }^{\text {coverage }^{\mathrm{a}}}\end{array}$ & $\begin{array}{c}\text { Degree of } \\
\text { centralisation }\end{array}$ & $\begin{array}{c}\text { Coordination } \\
\text { of wage } \\
\text { bargaining }\end{array}$ & $\begin{array}{c}\text { Degree of } \\
\text { coordination }\end{array}$ & $\begin{array}{c}{ }^{\mathrm{b}} \text { State } \\
\text { interference in } \\
\text { private-sector } \\
\text { wage } \\
\text { bargaining }\end{array}$ \\
\hline Belgium & $54 \%$ & $90 \%$ & 10 & $\begin{array}{l}\text { State-imposed } \\
\text { (SI) }\end{array}$ & 2 & $\begin{array}{l}\text { SI: Unilateral } \\
\text { regulation }\end{array}$ \\
\hline Denmark & $76 \%$ & $69 \%$ & 14 & $\begin{array}{l}\text { State- } \\
\text { sponsored } \\
\text { (SS) }\end{array}$ & 3 & $\begin{array}{c}\text { SS: } \\
\text { conciliation }\end{array}$ \\
\hline Spain & $19 \%$ & $78 \%$ & 7 & $\begin{array}{c}\text { Intra- } \\
\text { associational }\end{array}$ & 2 & $\begin{array}{l}\text { Non- } \\
\text { interference }\end{array}$ \\
\hline Ireland & $46.2 \%$ & $66 \%$ & 6 & $\begin{array}{c}\text { State- } \\
\text { sponsored } \\
(\mathrm{SS})\end{array}$ & 1 & $\begin{array}{l}\text { SS: Tripartism } \\
\text { without } \\
\text { authoritative } \\
\text { implementation }\end{array}$ \\
\hline Italy & $39 \%$ & $82 \%$ & 5 & $\begin{array}{l}\text { State- } \\
\text { sponsored } \\
\text { (SS) }\end{array}$ & 2.5 & $\begin{array}{l}\text { SS: Tripartism } \\
\text { without } \\
\text { authoritative } \\
\text { implementation }\end{array}$ \\
\hline
\end{tabular}

In many countries, mandatory and voluntary extension mechanisms extend the results of collective agreements between unions and employers to non-unionised workers and firms. This is the case in Belgium, Italy and Spain. That explains the high level of the collective bargaining coverage in these countries. The highest level is recorded in Belgium (90\%) and the lowest in Ireland (66\%).

According to the ranking of table 3 and to the OECD (1997) Denmark can be considered as the most centralised country of the five. This is due to its centralised procedure of conciliation and its high degree of coordination of wage bargaining. Belgium comes next. The centralisation in Belgium is mainly due to the state-imposed regulation. However, the ranking of the degree of centralisation of Italy is low, this country benefit from a high level of coordination. In Spain, the coordination is average and the State does not interfere in the private sector wage bargaining, it is a quite decentralised country. The most decentralised and non-coordinated country of our sample is Ireland.

It will be showed later in this study that the size of the gender wage gap follows this ranking. We will also confirm that gender wage gap is influenced by the level of wage inequality in a country. 


\section{Methodology}

\subsection{Oaxaca and Binder (1973) decomposition}

The traditional decomposition (Oaxaca 1973 and Blinder 1973) is based on the Mincer earnings function (1958):

$$
\ln w_{i}=a_{i}+x_{i} \beta_{i}+u_{i}
$$

The index refers to an individual $i, w_{i}$ denotes the wage, $a_{i}$ the equation constant, $x_{i}$ the observed characteristics, $\beta$ the characteristic prices and $u_{i}$ the unexplained part of the wage equation. The latter corresponds to both unobserved characteristics and their prices.

Oaxaca and Binder's (1973) decomposition requires separate estimation of the wage equation for men and women.

$$
\begin{aligned}
& \ln \bar{w}^{f}=a^{f}+\beta^{f} \bar{x}^{f} \\
& \ln \bar{w}^{m}=a^{m}+\beta^{m} \bar{x}^{m}
\end{aligned}
$$

The $m$ and $f$ indexes refer to men and women respectively, $\bar{w}^{m} / \bar{w}^{f}$ denotes the average wage of men/women, $a^{m} / a^{f}$ the intercept of the wage equation men/women and $\bar{x}^{m} / \bar{x}^{f}$ the average observed characteristics of men/women.

$\ln \bar{w}^{m}-\ln \bar{w}^{f}=\beta^{m}\left(\bar{x}^{m}-\bar{x}^{f}\right)+\left[\left(a^{m}-a^{f}\right)+\bar{x}^{f}\left(\beta^{m}-\beta^{f}\right)\right]$

In this equation, the first term represents the explained part: the differences between men and women in individual characteristics, $x$. The second term gives the unexplained part. This last term regroups the unobserved characteristic differences and the differentials in return for equal characteristics between men and women.

Note that this equation suffers from an index problem: modifying the weights used would change the value of each component that is calculated. In the literature, the choice of men as reference is motivated by the fact that estimations based on male sample are less affected by selection bias.

Oaxaca and Binder's (1973) decomposition does not take into account the wage structure. International comparisons of the gender wage gap have shown that such a factor does have an impact on the wage gap of a country (Rowthorn, 1992; Withehouse, 1992; Rubery and Fragan, 1994). The wage gap decomposition developed by Juhn and al. (1991) allows the consideration of the wage structure.

\subsection{Taking the wage structure into account, the Juhn-Murphy-Pierce (1991) decomposition}

The Juhn and al. model supposes the male wage equation as following:

$$
\ln \bar{w}_{a}^{m}=a^{m}+\bar{x}_{a}^{m} \beta_{a}^{m}+\sigma_{a} \bar{\theta}_{a}^{m}
$$


where $\sigma_{a}$ is the standard deviation of the men's wage residual distribution and, $\bar{\theta}_{a}^{m}$ is the women's average position in the men's residual distribution.

The average gender wage gap for country $a$ can be written as follow:

$$
D_{a}=\ln \bar{w}_{a}^{m}-\ln \bar{w}_{a}^{f}=\left(x_{a}^{m}-x_{a}^{f}\right) \beta_{a}+\sigma_{a}\left(\theta_{a}^{m}-\theta_{a}^{f}\right)=\Delta x_{a} \beta_{a}+\sigma_{a} \Delta \theta_{a}
$$

The gender wage gap is hence decomposed in a part due to human capital differences $(x)$ between men and women and another part due to differences in the ranking of men and women in the male residual distribution (if women are located at the top or the bottom of the male wage residual distribution). This last element can reflect either the gender differences in terms of unobserved characteristics or the impact of the discrimination against women on the labour market.

A Blau and al. (1992)'s contribution has been to apply this decomposition to the analysis of the factors that influence the gender gap between countries (between country $a$ and $b$ for example). According to these authors, the wage gap difference between two countries can be decomposed as follows:

$$
D_{a}-D_{b}=\left(\Delta x_{a}-\Delta x_{b}\right) \beta_{b}+\Delta x_{a}\left(\beta_{a}-\beta_{b}\right)+\left(\Delta \theta_{a}-\Delta \theta_{b}\right) \sigma_{b}+\Delta \theta_{a}\left(\sigma_{a}-\sigma_{b}\right)
$$

The first term reflects the contribution of cross-country differences in observed characteristics to the wage gap difference. The second term estimates the impact of the different measured prices across countries for these observable characteristics. The third term measures the effect of inter-country differences in the relative wage position of women and men in the male residual distribution. Finally, the fourth term captures the international differences in the residual inequalities when the average women's rank of the country $a$ is applied to that of country $b$.

The first and the third terms represent the gender specific factors that affect the gap difference between countries. The second and the fourth terms measure the impact of the wage structure on this gap difference.

According to Suen (1997) standard deviation of residual wage and percentile ranks are not necessary independent. With rising wage inequality, the mean percentile rank of lowwage groups will rise simply because more dispersed distributions have ticker tails.

Comparing Oaxaca (1973) and Juhn and al. methods reveals that the term capturing the discrimination in Oaxaca-Blinder (1973) is the same as the component which indicates the women's rank in the male residual distribution in the Juhn and al. (1991) decomposition. An advantage of the latter method is the inclusion of the wage structure dimension. 
Jones $(1983)^{5}$ has shown that the discrimination term in the Oaxaca decomposition cannot be decomposed in order to identify the contribution of each price to this term. This is due to the use of dummy variables in the wage equation. The obtained value for such decomposition depends on the choice of the model reference category.

Within the framework of a cross-country comparison of the gender wage gap between two countries $a$ and $b$, the advantage of using the decomposition relating to the wage structure is stronger.

\subsection{Application of Oaxaca-Blinder's decomposition method to cross-national comparisons of the gender pay gap}

The adaptation of the Oaxaca-Blinder model for international comparison of the gender wage disparities has the advantage of taking into account factors that characterise the wage structure in each country. Using equation (4) for a country $a$ and $b$, the difference in gender pay gap between two countries can be written as following:

$$
\begin{aligned}
& D_{b}-D_{a}=\beta_{m}^{a}\left(\Delta \bar{x}_{b}-\Delta \bar{x}_{a}\right)+\Delta \bar{x}_{b}\left(\beta_{b}^{m}-\beta_{a}^{m}\right)+\Delta \beta_{a}\left(\bar{x}_{b}^{f}-\bar{x}_{a}^{f}\right) \\
& +\bar{x}_{b}^{f}\left(\Delta \beta_{b}-\Delta \beta_{a}\right)+\left(a_{b}-a_{a}\right)
\end{aligned}
$$

According to this decomposition, the differences between countries are due to five factors: (1) differences in observable individual endowments between women and men; (2) differences in prices for these characteristics; (3) differences in individual characteristics between women. Women have on average higher return to their productivity characteristics. For example, for a given (positive) gender difference in measured prices for experience, a higher level of experience (for both men and women) will raise the gender wage gap. This element highlights the fact that although women are improving their levels of productivity characteristics relative to men, this progress is reduced by the existence of gender differences in return to these characteristics; (4) differences in observed prices for equal characteristics between men and women and; (5) difference in residual inequalities.

\subsection{Taking the occupational and industrial segregation into account, Brown, Moon and Zoloth (1980) decomposition}

As mentioned above, the approach of Brown and al. (1980) differs from other studies in the literature because these authors do not introduce occupational variables to take into account occupational segregation.

\footnotetext{
${ }^{5}$ According to Oaxaca (1973) and Blinder (1973), the gender wage gap is decomposed in an explained part (E) and an unexplained part (D). In accordance with Blinder (1973), the unexplained part can be subdivided into a part due to coefficient differences (C) and another one due to differences between constants (U). Jones (1983) shows that the parts E and D are invariable related to the choice of the reference category. In contrast, the subdivision of $\mathrm{D}$ in $\mathrm{C}$ and $\mathrm{U}$ is influenced by the reference category choice. Thus, $\mathrm{U}$ increases (or decreases) if the reference category presents a large (small) wage gap. This reduces (or amplifies) the part of C. D cannot neither be decomposed nor be interpreted consistently because the results depend on the reference category.
} 
In the same fashion as Oaxaca, the wage equations are estimated separately for both men and women based on their individual characteristics (without occupational variables) for each occupation $j$.

The gender wage gap obtained is the following:

$$
\ln \bar{w}^{m}-\ln \bar{w}^{f}=\sum_{j=1}^{n}\left(p_{j}^{m}-p_{j}^{f}\right) \ln \bar{w}_{j}^{m}+\sum_{j=1}^{n} p_{j}^{f}\left(\ln \bar{w}_{j}^{m}-\ln \bar{w}_{j}^{f}\right)
$$

where $p_{j}^{m}, p_{j}^{f}$ are the sample proportions of men and women in the $j$ th occupation.

The first term of this gap represents the portion attributable to inter occupational differences. The second term gives the share of the gap due to intra occupational differences.

The gender gap can be further decomposed in a justifiable (first and second element of equation 11) an unjustifiable portion (third and fourth and fifth elements of equation 11). The OLS estimation of separate wage equations by gender and the mean characteristics give the following decomposition:

$$
\begin{aligned}
\ln \bar{w}_{m}-\ln \bar{w}_{f} & =\sum_{j=1}^{n} p_{j}^{f}\left(\bar{x}_{j}^{m}-\bar{x}_{j}^{f}\right) \beta_{j}^{m}+\sum_{j=1}^{n} \ln \bar{w}_{j}^{m}\left(p_{j}^{m}-p_{j}^{f^{\prime}}\right) \\
& +\sum_{j=1}^{n} p_{j}^{f} \bar{x}_{j}^{f}\left(\beta_{j}^{m}-\beta_{j}^{f}\right)+\sum_{j=1}^{n} \ln \bar{w}_{j}^{m}\left(p_{j}^{f^{\prime}}-p_{j}^{f}\right) \\
& +\sum_{j=1}^{n} p^{f}\left(a_{j}^{m}-a_{j}^{f}\right)
\end{aligned}
$$

where $p_{j}^{f^{\prime}}$ measures the predicted share of women in the $j t h$ occupation according to the model of male predicting occupational distribution.

In this model the gender wage gap is decomposition into five elements: (i) gender differences in individual characteristics, (ii) differences in occupational segregation between men and the simulated women's distribution (due to differences in gender productivity characteristics), (iii) differences in the return of these characteristics, (iv) differences in occupational segregation between the simulated women's distribution and the women's actual distribution (residual), (iv) differences in unobserved characteristics between men and women and their prices.

The second and fourth elements of this decomposition are obtained by estimating a reduced form multinomial logit model of occupational attainments for men. The probability of a male worker $i$ being in the $j$ th occupation is a function of worker characteristics, $z$ : 


$$
p_{i j}^{m}=\frac{\exp \left(z_{i}^{m} \gamma_{j}^{m}\right)}{\sum_{j=1}^{n} \exp \left(z_{i}^{m} \gamma_{j}^{m}\right)}
$$

The estimate of this model predicts $p_{j}^{f^{\prime}}$, the proportion of women that would be in each occupation if women where allocated between occupations according to the male occupation attainment model. This approach supposes that in a world without discrimination women would be distributed across occupations according to the male occupational mechanism.

Brown and al. showed that their decomposition is a particular case of the Oaxaca decomposition where the gender differences in occupational distribution are taken as exogenous and therefore part of the explained component. In the Brown and al. decomposition this part is further decomposition into an explained component and a residual component.

We have also performed the Brown and al. decomposition to account for the industrial segregation.

\section{Results \\ 4.1 The effect of human capital characteristics}

As mentioned above, Oaxaca and Blinder (1973) have decomposed the gender wage gap into an explained and a residual part. The former represents the gender differences in observed characteristics and the latter is constituted by the gender differences in observed characteristic prices and by the differences in the constant between men and women.

According to our calculations of the unadjusted gender wage gaps, this gap is the largest in Ireland (35.9\%) and the smallest in Denmark (18.8\%). Taking into account productive individual characteristic endowments as well as their remunerations for both men and women, we obtain adjusted gender wage gaps. 
Table 5: Oaxaca decomposition in Europe

\begin{tabular}{|c|c|c|c|c|}
\hline & Gap & Explained Part & Residua & I Part \\
\hline & $D=\ln \bar{w}^{m}-\ln \bar{w}^{f}$ & $\beta^{m}\left(\bar{x}^{m}-\bar{x}^{f}\right)$ & $\left(a^{m}-a^{f}\right)+\bar{x}^{f}$ & $\left(\beta^{m}-\beta^{f}\right)$ \\
\hline Belgium & 0.2000 & 0.0832 & 0.1168 & \\
\hline$\%$ due to & & $41.60 \%$ & & $58.40 \%$ \\
\hline Denmark & 0.1881 & 0.0121 & 0.1761 & \\
\hline$\%$ due to & & $6.41 \%$ & & $93.61 \%$ \\
\hline Spain & 0.3043 & 0.0635 & 0.2406 & \\
\hline$\%$ due to & & $20.88 \%$ & & $79.06 \%$ \\
\hline Ireland & 0.3591 & 0.1414 & 0.2177 & \\
\hline$\%$ due to & & $39.38 \%$ & & $60.62 \%$ \\
\hline Italy & 0.2450 & 0.0563 & 0.1886 & \\
\hline$\%$ due to & & $22.99 \%$ & & $77.00 \%$ \\
\hline
\end{tabular}

Belgium, and Ireland record a better score at the adjusted level in comparison with the unadjusted one. These results imply that in these countries, introducing gender differences in characteristics between workers explains an important part of the gap.

In all countries, the explained part is smaller than the residual one. The residual part is the largest in Denmark (93.6\%) and the smallest in Belgium and in Ireland (58.4\% and $60.6 \%$ respectively). These results suppose that discrimination or unobserved characteristics play a more important role regarding gender disparities than observed characteristics. Particularly concerning Denmark, it is noteworthy that in this country, which records the smallest gender wage gap and few differences in productive characteristics between men and women, more that $90 \%$ of the wage gap cannot be explained by human capital variables.

The gender wage gaps (both unadjusted and adjusted) are smaller in the two countries, which present more developed gender specific policies arrangements, i.e. Denmark and Belgium.

\subsection{The wage structure}

Remember that Blau and Khan (1992) have adapted the Juhn and al. (1991) decomposition in order to compare the inter-country gender wage gap. This technique divides the wage gap into a part due to specific-gender factors and a part due to the wage structure. In this decomposition, the wage structure is considered by the standard deviation of the residuals of men's wages and by the women's relative rank in the residual distribution of men's wages.

The advantage of this decomposition consists in the possibility to decompose the residual and to identify the effects that are related to the wage structure. 
Table 6: cross-countries differential decomposition (Juhn, Murphy and Pierce), Belgium as reference country

\begin{tabular}{|c|c|c|c|c|c|c|}
\hline & Di-Dbel & $\begin{array}{l}\text { Mean female } \\
\text { Residual rank } \\
\end{array}$ & $\begin{array}{l}\text { Male residual } \\
\text { Std. Dev. }\end{array}$ & $\begin{array}{c}\text { Male log. wage } \\
\text { Std. Dev. }\end{array}$ & & \\
\hline Belgium & -- & 32 & 0.290 & 0.414 & & \\
\hline Denmark & -0.006 & 28 & 0.265 & 0.343 & & \\
\hline Ireland & 0.159 & 31.7 & 0.443 & 0.587 & & \\
\hline Italy & 0.045 & 29.2 & 0.315 & 0.433 & & \\
\hline \multirow[t]{2}{*}{ Spain } & 0.104 & 25.7 & 0.390 & 0.543 & & \\
\hline & Observed Xs & $\begin{array}{c}\text { Observed } \\
\text { prices }\end{array}$ & Rank & $\begin{array}{c}\text { Unobserved } \\
\text { prices }\end{array}$ & Sum gender & Sum wage \\
\hline Country & $\beta_{a}\left(\Delta \bar{x}_{b}-\Delta \bar{x}_{a}\right)$ & $\Delta \bar{x}_{b}\left(\beta_{b}-\beta_{a}\right)$ & $\left(\Delta \theta_{b}-\Delta \theta_{a}\right) \sigma_{a}$ & $\Delta \theta_{b}\left(\sigma_{b}-\sigma_{a}\right)$ & Specific & Structure \\
\hline Denmark & -0.025 & -0.046 & 0.076 & -0.011 & 0.051 & -0.057 \\
\hline Ireland & 0.007 & 0.051 & 0.026 & 0.075 & 0.033 & 0.126 \\
\hline Italy & 0.001 & -0.028 & 0.057 & 0.015 & 0.058 & -0.013 \\
\hline $\begin{array}{l}\text { Spain } \\
\text { Average }\end{array}$ & -0.025 & 0.005 & 0.062 & 0.061 & 0.037 & 0.067 \\
\hline Unweighted & -0.011 & -0.004 & 0.055 & 0.035 & 0.045 & 0.031 \\
\hline
\end{tabular}

At an international comparison level, this technique identifies four factors of intercountry gender pay disparities: 1) gender differences in observed productivity characteristics, 2) differences in country prices of observed productivity characteristics, 3 ) differences in the women's relative rank in the male residual wage distribution, and 4) price differences in the unobserved characteristics.

We have chosen to carry out decompositions taking Belgium as our reference country. This country presents interesting genre and wage structure features. According to our results Denmark is, as expected, the only country with a negative gender gap.

The mean female residual rank ranges from 25.7 in Spain to 32 in Belgium.

Wage inequality also varies between countries. This inequality is smaller in Denmark, Belgium and Italy. As a matter of fact, the standard deviation of the logarithm of male wages is about $0.34,0.41$ and 0.43 respectively in these latter countries and of a higher level in Spain and Ireland ( 0.54 and 0.59 respectively). The figures of the residual standard deviation of the logarithm of male wages show the same patterns at a lower level. These findings are in accordance with the literature suggesting that countries that 
exhibit lower wage inequality, Denmark, Belgium and Italy, have lower gender wage gap.

The contribution of observed productivity characteristics on cross-country gender wage gap is negative for Denmark and Spain and positive for Ireland and Italy. This suggest that this component has a positive effect on the Danish and the Spanish gap, indicating that women in these countries have relatively favourable levels of measured variables compared with Belgium (the unweighted average effect is -0.011). On the other hand, this element raises the gap of Ireland and Italy compared with Belgium. Note that this relative good score of Spain is mainly due to the important educational differential between Spanish men and women, the most important among the five countries $(-0.5$ years of schooling in favour of women, see descriptive statistics in appendix).

The figure related to male returns to explanatory variables is negative for Denmark and Italy and positive for the other countries. This means that the relative low return in Denmark and in Italy reduces the gap relative to Belgium. Ireland and Spain have higher male prices of observer productive characteristics, which has a negative effect on their wage gap.

The results on the ranking position of women in the male residual distribution show that these differences in ranking raise considerably the gender wage gap of all others countries relative to that of Belgium (the unweighted average effect is 0.055). This also means that Belgium has the smallest portion of residual in its gender wage gap in comparison with all other countries under study.

The same way, our findings indicate that the lower level of residual wage inequality in Belgium has a positive effect on its gender wage gap in comparison to all other countries, excepted Denmark (the unweighted average effect is 0.035 ). In fact, we have seen that Denmark and Belgium have the more concentrated wage distribution among the five European countries.

To sum up, we observe that the total effect of gender-specific factors is largely in favour of Belgium and explains the narrow gender wage gap of this country (the unweighted average effect is 0.045 ). The total effect of wage structure factor helps also to explain the small gender wage gap in Belgium (the unweighted average effect is 0.031). In fact, the Belgian wage structure is more concentrated relative to that of Ireland and Spain. On the other hand, the total effect of this later element is more in favour of Denmark and Italy.

In addition, Belgium aside the total effect of gender-specific factor is the most positive for Ireland and Spain (the closest differentials relative to Belgium), Denmark and Italy record larger differentials at this level. The Irish women are advantaged by their high position in the wage residuals of Irish men (relatively small percentage of residual in the gender wage gap). We have seen that Denmark has the smallest observed gender productivity characteristics differential with Spain. Danish women seem to particularly suffer from their low rank in the male residual distribution (relatively high percentage of residual in the gender wage gap). Total effect of the wage structure reduces the pay gap in Denmark and Italy relative to the other countries. Ireland and Spain have high levels of 
wage inequality. Finally, taking the wage setting system (centralised/decentralised) into account, we see that countries differ the most by the effects of gender specific factors on the gender wage gap.

\subsection{The application of the Oaxaca-Binder decomposition method to cross- national comparisons of the gender pay gap}

We have extended the Oaxaca model to allow an international comparison of gender wage disparities.

Table 7: Cross-countries differential decomposition (Oaxaca), Belgium as reference country

\begin{tabular}{lcccccc}
\hline \hline Country & Di-Dbel & $\begin{array}{c}\text { Observed Xs } \\
\beta_{m}^{a}\left(\Delta \bar{x}_{b}-\Delta \bar{x}_{a}\right)\end{array}$ & $\begin{array}{c}\text { Observed Ps } \\
\Delta \bar{x}_{b}\left(\beta_{b}-\beta_{a}\right)\end{array}$ & $\begin{array}{c}\text { Female Xs } \\
\Delta \beta_{a}\left(\bar{x}_{b}^{f}-\bar{x}_{a}^{f}\right)\end{array}$ & $\begin{array}{c}\text { Diff. observed Prices } \\
\bar{x}_{b}^{f}\left(\Delta \beta_{b}-\Delta \beta_{a}\right)\end{array}$ & $\begin{array}{c}\text { Residual } \\
\left(\Delta a_{b}-a_{a}\right)\end{array}$ \\
Denmark & -0.012 & -0.025 & -0.046 & 0.005 & -0.496 & 0.551 \\
Ireland & 0.159 & 0.007 & 0.051 & -0.091 & -0.367 & 0.559 \\
Italy & 0.045 & 0.001 & -0.028 & -0.014 & -2.265 & 2.352 \\
Spain & 0.104 & -0.025 & 0.005 & 0.012 & -1.090 & 1.202 \\
$\begin{array}{l}\text { average } \\
\text { unweighted }\end{array}$ & & -0.011 & 1.087 & -0.022 & -1.055 & 1.166 \\
\hline \multicolumn{2}{r}{ Source: Author's calculations - ESES 1995 }
\end{tabular}

In comparison with the Juhn and al. decomposition, this approach adds interesting information on the contribution of differences in return to observed productive characteristics and level of female characteristics across country to cross-country gender wage gap differentials.

Spanish, Danish and Belgian women have higher levels of productive characteristics than the Italian and Irish women. This component raises the gap in Belgium in comparison with the other countries (the unweighted average effect is -0.022).

The figure on the contribution of differences in prices of observed productivity characteristics between men and women is negative for all countries (the unweighted average effect is -1.055). This indicated that this higher level of differentials raise the Belgian gap relative to all other countries.

Belgium beside, our results show that this kind of differential is the most important in Denmark and Ireland. Italy and Spain record the smallest gender differences.

It is interesting to note that countries, which record the lowest gender wage gap and gender differences in observed productivity characteristics as well as high levels of productivity characteristics, Denmark and Belgium, are countries recording significant 
differences in return for these characteristics. This observation is the most important since the larger the difference in return to qualifications, the more the high level of productive characteristics increases the gender wage gap.

\subsection{Occupational and industrial segregation ${ }^{6}$}

We used the method developed by Brown and al. (1980) in order to simulate the female occupational distribution according to that of men.

Table 8: Distribution by Occupation

\begin{tabular}{|c|c|c|c|c|c|c|c|c|}
\hline Occupation $^{1}$ & 1 & 2 & 3 & 4 & 5 & 7 & 8 & 9 \\
\hline \multicolumn{9}{|l|}{ Denmark } \\
\hline Women's Actual Distrib & $2.42 \%$ & $5.25 \%$ & $25.76 \%$ & $24.82 \%$ & $11.65 \%$ & $2.68 \%$ & $16.73 \%$ & $10.68 \%$ \\
\hline Women's Predicted Distrib & $5.80 \%$ & $6.63 \%$ & $21.84 \%$ & $10.30 \%$ & $8.38 \%$ & $14.57 \%$ & $18.28 \%$ & $14.21 \%$ \\
\hline Men's Actual Distrib & $8.13 \%$ & $10.08 \%$ & $18.71 \%$ & $4.88 \%$ & $4.62 \%$ & $21.22 \%$ & $21.33 \%$ & $11.02 \%$ \\
\hline Percentage of change & $139.42 \%$ & $26.47 \%$ & $-15.22 \%$ & $-58.51 \%$ & $-28.10 \%$ & $443.28 \%$ & $9.21 \%$ & $33.03 \%$ \\
\hline \multicolumn{9}{|l|}{ Belgium } \\
\hline Women's Actual Distrib & $3.87 \%$ & $6.24 \%$ & $12.72 \%$ & $42.10 \%$ & $11.48 \%$ & $5.76 \%$ & $5.38 \%$ & $12.45 \%$ \\
\hline Women's Predicted Distrib & $6.53 \%$ & $7.76 \%$ & $18.68 \%$ & $17.12 \%$ & $4.63 \%$ & $22.50 \%$ & $13.65 \%$ & $9.12 \%$ \\
\hline Men's Actual Distrib & $8.36 \%$ & $7.53 \%$ & $18.57 \%$ & $16.86 \%$ & $4.16 \%$ & $21.48 \%$ & $14.06 \%$ & $9.00 \%$ \\
\hline Percentage of change & $68.79 \%$ & $24.33 \%$ & $46.90 \%$ & $-59.33 \%$ & $-59.66 \%$ & $290.61 \%$ & $153.77 \%$ & $-26.71 \%$ \\
\hline \multicolumn{9}{|l|}{ Italy } \\
\hline Women's Actual Distrib & $0.48 \%$ & $1.87 \%$ & $6.07 \%$ & $39.31 \%$ & $12.83 \%$ & $20.91 \%$ & $11.33 \%$ & $7.20 \%$ \\
\hline Women's Predicted Distrib & $1.34 \%$ & $3.38 \%$ & $13.96 \%$ & $17.62 \%$ & $5.76 \%$ & $29.50 \%$ & $21.77 \%$ & $6.67 \%$ \\
\hline Men's Actual Distrib & $2.35 \%$ & $4.41 \%$ & $13.27 \%$ & $16.21 \%$ & $5.80 \%$ & $28.85 \%$ & $22.11 \%$ & $7.00 \%$ \\
\hline Percentage of change & $181.01 \%$ & $80.39 \%$ & $130.06 \%$ & $-55.17 \%$ & $-55.12 \%$ & $41.07 \%$ & $92.13 \%$ & $-7.34 \%$ \\
\hline \multicolumn{9}{|l|}{ Spain } \\
\hline Women's Actual Distrib & $1.50 \%$ & $4.06 \%$ & $9.47 \%$ & $34.83 \%$ & $15.07 \%$ & $6.98 \%$ & $13.48 \%$ & $14.61 \%$ \\
\hline Women's Predicted Distrib & $3.41 \%$ & $5.46 \%$ & $11.22 \%$ & $11.04 \%$ & $8.32 \%$ & $25.01 \%$ & $22.55 \%$ & $13.00 \%$ \\
\hline Men's Actual Distrib & $4.82 \%$ & $5.82 \%$ & $11.58 \%$ & $10.33 \%$ & $7.33 \%$ & $24.94 \%$ & $23.64 \%$ & $11.55 \%$ \\
\hline Percentage of change & $127.09 \%$ & $34.32 \%$ & $18.51 \%$ & $-68.31 \%$ & $-44.82 \%$ & $258.50 \%$ & $67.28 \%$ & $-11.02 \%$ \\
\hline
\end{tabular}

The simulated distribution differs quite much from the observed female distribution. The direction of the evolution per occupation is the same across all countries, except for the Danish occupational categories of Professional (3) and Elementary Occupations (9) that go in the opposite direction than the other countries.

We observe a significant investment of women through male occupations and a desertion from typically women's. Therefore, if we observed the simulated distribution, more

\footnotetext{
${ }^{6}$ This part of the analysis does not contain Ireland for comparability reasons. There is a lack of certain occupations and sectors in the Irish data set.
} 
women would have been employed in high paid occupations with supervisor responsibilities as Legislators and Senior Officials (1), Professionals (2) or, Technicians and Associate Professionals (3). On the basis of the simulated distribution the portion of women in the Legislators' and Senior Officials' occupations would increase by $181 \%$ in Italy, about $139 \%$ in Denmark and 127\% in Spain. Women would be less concentrated in subordinate and low paid occupations. For instance, the share of female clerks decreases about $68 \%$ in Spain and about 58-59\% in Denmark and Belgium.

Another way to perceive the reduction in occupational segregation that would occur if women had the same attainment possibilities as men, is to analyse the evolution of the gender segregation index. Occupational segregation is almost always measured by Duncan's index ${ }^{7}$, which is a measure of the dissimilarity between two distributions. This index is calculated as following:

$$
D=\frac{1}{2} \sum_{i}\left|p_{i m}-p_{i f}\right|
$$

where $p_{i m}$ is the percentage of men employed in the ith occupation and $p_{i f}$ is the portion of women employed in the same occupation (the ith). This index ranges from 0 , in case of perfect similarity (whether men and women are identically allocated across occupations and sectors), to 1 , in case of perfect dissimilarity.

Table 9: Gender segregation indexes by 1-Digit Occupation

\begin{tabular}{lcccc}
\hline \hline & Belgium & Denmark & Italy & Spain \\
\hline D observed & 0.360 & 0.340 & 0.303 & 0.353 \\
& & & & \\
D simulated & 0.022 & 0.030 & 0.028 & 0.032 \\
\hline \multicolumn{2}{l}{ Source: Author's calculations - ESES 1995 }
\end{tabular}

According to our results Belgium is the country with the highest occupational segregation and Italy, the lowest. The dissimilarity indexes calculated on basis of the actual distribution vary from 0.303 in Italy to 0.36 in Belgium. In case of women's occupational attainment as men, the occupational segregation would be the highest in Spain (0.032) and the lowest in Belgium (0.022). As a matter of fact, the indexes computed with the estimate female distribution are very close to zero (case of perfect similarity. This confirms the accuracy of our attainment model.

With the help of the simulated female occupational distributions, we have carried out the decomposition of the gender wage for the five countries according to the method developed by Brown and al. (1980).

\footnotetext{
${ }^{7}$ Duncan and Duncan (1955)
} 
Table 10: Brown, Moon and Zoloth decomposition in Europe, occupations

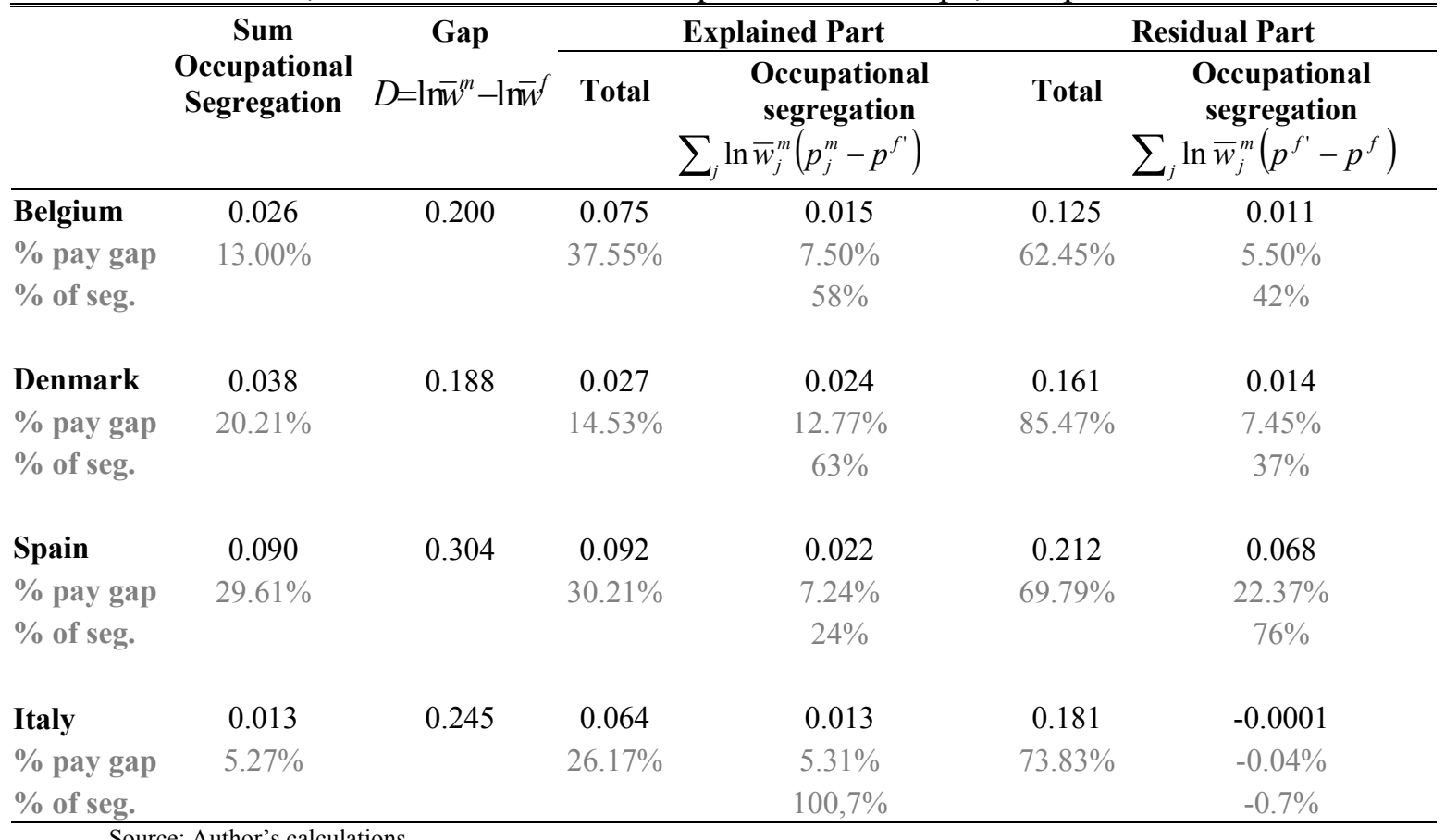

Source: Author's calculations

The table 10 gives the components of the explained and the residual part, which are due to occupational segregation.

In comparison with the results of the Oaxaca and the Juhn and al. decompositions the explained (residual) component has decreased (increased) in all the countries, except in Belgium. This is normal, as we have performed the former decomposition not accounting for occupational distribution. So that this information was stocked into the residual part, which declines now that we use this information with the Brown and al. decomposition. Only the Belgian result is surprising.

Recall that with this approach, the explained part does not receive the entire effect of occupational segregation. This latter component is divided into an explained and a residual component.

The occupational segregation accounts for the most important part of the gender wage gap in Spain (29.6\%) and in Denmark (20.2\%). The segregation is lower in Belgium $(13 \%)$ and rather small in Italy $(5.3 \%)$. In Italy around $100 \%$ of the segregation is due to gender differences in productivity characteristics. This portion is quite beyond the average for Denmark and for Belgium (63\% and 58\% respectively). In Spain only $25 \%$ of the high level of segregation is explained by productivity characteristics. Therefore we see that a significant part of the occupational segregation cannot be explained by observed productivity characteristics. 
We have also performed the Brown and al. approach in order to identify the contribution of industrial segregation to the gender pay gap.

The same way as for occupational segregation the table 11 gives the simulated female industrial distribution according to that of men.

Table 11: Distribution by Sector

\begin{tabular}{|c|c|c|c|c|c|c|c|c|c|}
\hline Sector $^{1}$ & 1 & 2 & 3 & 4 & 5 & 6 & 7 & 8 & 9 \\
\hline \multicolumn{10}{|l|}{ Denmark } \\
\hline Women's Actual Distribution & $0.18 \%$ & $35.94 \%$ & $0.70 \%$ & $1.97 \%$ & $22.69 \%$ & $2.32 \%$ & $4.27 \%$ & $16.22 \%$ & $15.71 \%$ \\
\hline Women's Predicted Distribution & $0.33 \%$ & $27.93 \%$ & $0.73 \%$ & $6.58 \%$ & $27.27 \%$ & $2.74 \%$ & $6.71 \%$ & $18.11 \%$ & $9.59 \%$ \\
\hline Men's Actual Distribution & $0.55 \%$ & $43.06 \%$ & $1.12 \%$ & $10.32 \%$ & $19.00 \%$ & $0.89 \%$ & $5.65 \%$ & $7.48 \%$ & $11.93 \%$ \\
\hline Percentage of change & $85.4 \%$ & $-22.3 \%$ & $3.8 \%$ & $233.8 \%$ & $20.2 \%$ & $18.2 \%$ & $57.0 \%$ & $11.7 \%$ & $-39.0 \%$ \\
\hline \multicolumn{10}{|l|}{ Belgium } \\
\hline Women's Actual Distribution & $0.08 \%$ & $25.96 \%$ & $0.83 \%$ & $1.09 \%$ & $23.54 \%$ & $2.78 \%$ & $6.90 \%$ & $17.36 \%$ & $21.46 \%$ \\
\hline Women's Predicted Distribution & $0.29 \%$ & $47.80 \%$ & $1.96 \%$ & $7.04 \%$ & $13.56 \%$ & $1.29 \%$ & $8.13 \%$ & $8.83 \%$ & $11.10 \%$ \\
\hline Men's Actual Distribution & $0.31 \%$ & $47.39 \%$ & $2.52 \%$ & $6.70 \%$ & $12.98 \%$ & $1.09 \%$ & $9.29 \%$ & $9.36 \%$ & $10.37 \%$ \\
\hline Percentage of change & $284.9 \%$ & $84.2 \%$ & $134.9 \%$ & $543.7 \%$ & $-42.4 \%$ & $-53.5 \%$ & $17.9 \%$ & $-49.2 \%$ & $-48.3 \%$ \\
\hline \multicolumn{10}{|l|}{ Italy } \\
\hline Women's Actual Distribution & $0.53 \%$ & $50.56 \%$ & $1.18 \%$ & $2.31 \%$ & $12.97 \%$ & $4.40 \%$ & $9.49 \%$ & $5.47 \%$ & $13.09 \%$ \\
\hline Women's Predicted Distribution & $0.86 \%$ & $51.00 \%$ & $2.94 \%$ & $6.22 \%$ & $6.25 \%$ & $2.25 \%$ & $17.98 \%$ & $5.28 \%$ & $7.22 \%$ \\
\hline Men's Actual Distribution & $0.94 \%$ & $48.97 \%$ & $3.24 \%$ & $6.53 \%$ & $6.19 \%$ & $2.35 \%$ & $19.10 \%$ & $5.31 \%$ & $7.37 \%$ \\
\hline Percentage of change & $63.9 \%$ & $0.9 \%$ & $148.4 \%$ & $169.3 \%$ & $-51.8 \%$ & $-48.8 \%$ & $89.4 \%$ & $-3.4 \%$ & $-44.8 \%$ \\
\hline \multicolumn{10}{|l|}{ Spain } \\
\hline Women's Actual Distribution & $0.19 \%$ & $34.72 \%$ & $0.71 \%$ & $3.22 \%$ & $27.77 \%$ & $9.57 \%$ & $6.75 \%$ & $6.91 \%$ & $10.17 \%$ \\
\hline Women's Predicted Dist. & $1.13 \%$ & $38.84 \%$ & $1.49 \%$ & $15.10 \%$ & $17.97 \%$ & $4.97 \%$ & $8.05 \%$ & $5.97 \%$ & $6.49 \%$ \\
\hline Men's Actual Distribution & $1.20 \%$ & $40.49 \%$ & $1.93 \%$ & $15.30 \%$ & $16.35 \%$ & $4.46 \%$ & $8.17 \%$ & $6.43 \%$ & $5.68 \%$ \\
\hline Percentage of change & $510.5 \%$ & $11.9 \%$ & $109.1 \%$ & $368.7 \%$ & $-35.3 \%$ & $-48.1 \%$ & $19.3 \%$ & $-13.6 \%$ & $-36.2 \%$ \\
\hline
\end{tabular}

This time again, we observe some important changes between the actual female distribution and the simulate one. Nevertheless, these latter are less significant than those obtained for occupational segregation. Industrial segregation is lower than occupational segregation. The direction of change is the same across countries as well, excepted for 3 sectors in Denmark ${ }^{8}$.

Generally speaking, our results indicate an increase of the share of women's employment in relative male sectors and a decrease in relative female sectors. In particular, the portion of women has decreased in the sectors of Trade (5) and, Hotels and Restaurants (6), which are known as low paid sectors. The same way, women are now less numerous in

\footnotetext{
${ }^{8}$ Those are (2) Manufacturing (D), (5) Wholesale and retail trade; repair of motor vehicles, motorcycles and personal and household goods $(\mathrm{G})$ and, (6) Hotels and restaurants $(\mathrm{H})$
} 
the Financial Intermediation (8) and the Real Estate, Renting and Business Activities (9) sectors, which this time are well paid sectors.

Therefore we cannot conclude that this redistribution of women by sector according to the male attainment model would have only positive effects on women's wages, even if the global effect could be positive.

Our computations of the dissimilarity index on industrial segregation confirms that industrial segregation is lower that occupational segregation for all the five countries.

Table 12: Gender segregation indexes by 1-Digit Sectors

\begin{tabular}{lcccc}
\hline \hline & Belgium & Denmark & Italy & Spain \\
\hline D observed & 0.313 & 0.176 & 0.163 & 0.215 \\
D simulated & 0.023 & 0.022 & 0.021 & 0.029 \\
\hline \multicolumn{2}{l}{ Source: Author's calculations - ESES 1995 }
\end{tabular}

On basis of the actual distribution, the ranking by country according to the industrial segregation is the same as that for occupational segregation. Italy records the lower level (0.163) and Belgium the highest (0.313). In case of the same industrial attainment for men and women, the segregation indexes decrease largely for all countries and are close to zero.

Carrying out a Brown and al. decomposition allow us to identify the part of the gender wage gap with is due to industrial segregation.

Table 13: Brown, Moon and Zoloth decomposition in Europe, sectors

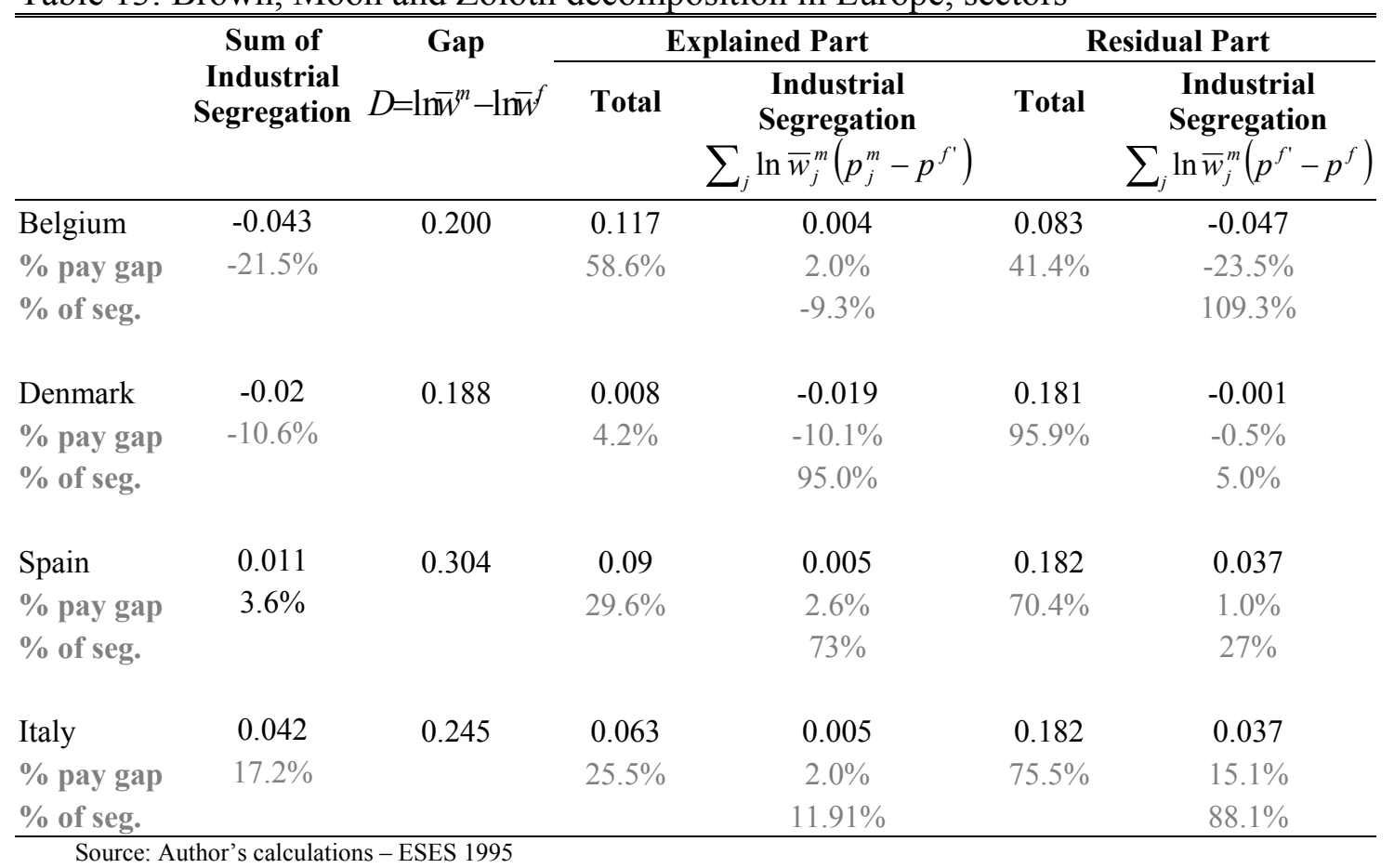


As expected, the explained (residual) component has decreased (increased) in all the countries (expect in Denmark).

The industrial segregation is positive in Spain and in Italy. It accounts for $3.6 \%$ and $17.2 \%$ respectively. We then observe that Italy is a country where occupational segregation accounts for a very low part of the pay gap and industrial segregation for an important part. The occupational segregation is mainly due to gender differences in observed productivity characteristics, while the industrial one remains largely unexplained. In Spain it is the opposite, the industrial segregation is very low, while the occupational segregation is more important. The occupational segregation is mainly residual and the industrial one explained at $73 \%$.

We have found a negative effect of industrial segregation on the wage gap of Belgium and Denmark. A further step in this study will be to check for the significance of components of wage decompositions using the delta method (Oaxaca and Ransom, 1998) or bootstrap (Efron and Tibshirani, 1986).

\section{Conclusions and policy suggestions}

In this study we used a comparable set of microdata to analyse elements determining gender wage gaps across five European countries in 1995. We have used different methods to decompose the gender gap: Oaxaca-Blinder (1973), Blau and Khan (1996) and Brown and al. (1980). We have also developed an adaptation of the Oaxaca decomposition for international comparisons. On basis of this methodology we have estimated the effects of human capital, wage structure and occupational segregation on cross-country comparisons of the gender wage gap.

Our results of the Oaxaca-Blinder decomposition indicate that the effect of human capital variables accounts for $6.4 \%$ in Denmark to $41.6 \%$ in Belgium of pay differentials between men and women. This evidence is in line with the literature and points that the significance of differences in human capital in modelling gender pay differentials varies across countries. Nevertheless, a common fact among all countries under study is that these characteristics explain less than $50 \%$ of the pay gap.

International comparisons of wage differentials confirm that both gender-specific factors and wage structure play an important role as gender wage gap is concerned. The evidence of the Juhn, Murphy and Pierce decomposition points that the particularly concentrate wage structure in Belgium, Denmark and Italy significantly contributes to explain the relative low level of wage differentials in these countries. We observe the opposite effect regarding Ireland and Spain. In these later countries wage inequality is higher and works to increase pay differential in comparison with the other countries.

The striking results of the adaptation of the Oaxaca-Blinder decomposition for international comparisons are that countries, which record the lowest gender wage gap and gender differences in observed productivity characteristics as well as high levels of 
productive characteristics, Denmark and Belgium, are countries recording significant differences in return for these characteristics. This observation is the most important since the larger the difference in return to qualifications, the more the high level of productive characteristics increases the gender wage gap. This finding questions the efficiency of equal pay legislation for these two countries.

Further, in this study we have also estimated the effect of occupational and industrial segregation on gender pay gap. First of all, according to the index of dissimilarity calculated on basis of the actual occupational and industrial distributions, the segregation is the most important in Belgium and the smallest in Italy. The industrial segregation is lower than the occupational one for all the countries under study. When using the simulated distribution the indexes reduce a great deal and are close to zero (case of perfect similarity between men and women). Evidence bases on the Brown, Moon and Zoloth decomposition points that the part of the gender pay differential due to occupational segregation ranges from $5.27 \%$ in Italy to $29.61 \%$ in Spain. This component can be fully explained by differences in observed productivity characteristics between men and women in Italy. These differences account only for 58-63\% in Belgium and in Denmark and for 24\% in Spain. Our findings for industrial segregation show that this element accounts for $3.6 \%$ of the Spanish gender wage gap and for $17.2 \%$ of that of Italy. $11.9 \%$ of the segregation of the latter country is explained by gender differences in human capital and $73 \%$ for the former. The results concerning industrial segregation for Belgium and Denmark have still to be revise (significance).

Finally, on basis of our results and a brief review of the legislation in force on gender equality and the wage setting systems in each of the five European countries under study, we can conclude by recommending some political suggestions to improve the situation regarding gender wage gap in these countries.

We suggest that Belgium and Denmark could improve the efficiency of their wage equality policies, in particular those aiming at ensuring equal pay for a work of equal value. In fact, these countries experience a large difference in returns of individual characteristics between men and women. Given the occupational segregation in Denmark measures should not be introduce at the occupational level but concern the whole working force.

We have seen concerning Spain that this country has small differences in return between men and women's characteristics and a good level of gender differences in productive characteristics. Therefore, the wage determination in this country being decentralised, the policies that aim to reduce the wage inequalities should produce positive effects on men and women's pay differentials. Concerning the gender specific measures in this latter country, the career break possibilities could be extended and the child-care systems for very young children improved. These measures could reduce the gender differences in terms of experience and tenure. Measures aiming at the reduction of the large unexplained part of the occupational segregation should also be considered. 
The wage dispersion is also important in Ireland although collective bargaining is run at the national level. Some measures to reduce this dispersion, such as the improving of extension mechanisms of collective bargaining or the strengthening of union power, could reduce the gap. In addition, this country could increase the compensation level of parental leaves and improve the child-care systems.

We have found that Italy, which has a narrow wage gap, has the smallest differences in return for observed productive characteristics among the five countries. Nevertheless, this country presents also important differences in individual characteristics and industrial segregation. This latter element remains mainly unexplained by differences in characteristics. Therefore, this country could improve its equality policies as well as its parental leave and child-care structures in order to better stabilise women's careers. 


\section{References}

1. Barbara Bergmann. "Does the Labour Market for Women's Labor Need Fixing?" Journal of Economic Perspectives 3 (Winter 1989): 43-60.

2. Francine D. Blau and Marianne Ferber. The Economics of Women, Men, and Work. Englewood Cliffs, NJ: Prentice-Hall, 1992.

3. Francine D. Blau and Lawrence M. Khan. "The Gender Earnings gap: Learning from International Comparisons". The American Economic Review 8, Papers and Proceedings of the Hundred and Fourth Annual Meeting of the American Economic Association (May 1992): 533-538.

4. Francine D. Blau and Lawrence M. Khan. "Wage structure and Gender Earnings Differentials: An international comparison". Economica 63 (May 1996): S29-S62.

5. Francine D. Blau and Lawrence M. Khan. "Swimming Upstream: trends in the Gender Wage Differential in the 1980s". Journal of Labor Economics 15 (January 1997): 1-42.

6. Alan S. Blinder. "Wage Discrimination: Reduced Form and Structural Estimates". Journal of Human Resources 8 (Autumn 1973): 436-455.

7. Randall S. Brown, Marilyn Moon and Barbara Zoloth, (1980), "Incorporating Occupational Attainment in Studies of Male-Female Earnings Differentials". The Journal of Human Resources 15 (Winter 1980): 3-28.

8. Rachel Connelly. "The Effect of Child Care Costs on Married Women's Labor Force Participation". Review of Economics and Statistics 4 (February 1992): 8390.

9. Otis D. Duncan and Beverly Duncan. "A methodological analysis of segregation indexes". American Sociological Review 20 (April 1955): 210-17.

10. B. Efron and R. Tibshirani. "Bootstrap measures for standard errors, confidence intervals, and other measures of statistical accuracy". Statistical Science 1 (February 1986): 54-75.

11. Brenda Gannon, Robert Plasman, François Rycx and Ilan Tojerow. "Interindustry wage differentials and the gender wage gap: Evidence from European countries". PiEP Working paper. The London School of Economics, 2004.

12. Janet Gornick and M. K. Meyers. "Public policies and Employment of Mothers: A Cross-National Study". Luxembourg Income Study Working Paper 140 (June 1996).

13. Janet Gornick. "Gender Equality in the Labour Market: Women's Employment and Earnings", Luxembourg Income Study Working Paper 206 (June 1999).

14. Damian Grimshaw, Jill Rubery and Hugo Figueiredo. "The Gender Pay Gap and Gender Mainstreaming Pay Policy in EU Member States". European Expert Group on Gender and Employment Report to the Equal Opportunities Unit, DG Employment (November 2002).

15. James Heckman. "Sample selection Bias as a Specification Error". Econometrica 47 (January 1979): 153-161.

16. F.L Jones. "On Decomposing the Wage Gap: A Critical Comment on Blinder's Method". Journal of Human Resources 28, (Winter 1983): 126-30. 
17. Chinhui Juhn, Kevin M. Murphy and Brooks Pierce. "Accounting for the Slowdown in Black- White Wage Convergence". In Workers and their Wages. eds. M.H. Kosters. AEI Press, 1991.

18. Chinhui Juhn, Kevin M. Murphy and Brooks Pierce. (1993), "Wage Inequality and the rise in Returns to skill". The Journal of Political Economy 101 (June 1993): 410-442.

19. Michael Kidd and Michael Shannon. "Does the level of Occupation Aggregation Affect Estimates of Gender Wage Gap?". Industrial and Labor Relations Review 49 (January 1996): 317-329.

20. Blandine Lejealle. "Les différences salariales en 1995". Document PSELL 124. CEPS/Instead, February 2001.

21. Charles Michalopoulos, Philip K. Robins and Irwin Garfinkel. "A Structural Model of Labor Supply and Child Care Demand". The Journal of Human Resources 27 (Winter 192): 166-203.

22. Jacob Mincer and Solomon W. Polachek. "Earnings of Women". Journal of Political Economy 82 (March/April 1974): S76-S108.

23. Nabanita Datta Gupta and Donna. S. Rothstein. "The Impact of Worker and Establishment-level Characteristics on Male-Female Wage Differential: evidence from Danish Matched Employee-Employed Data". Forthcoming Labour Economics, 2005

24. Stephen Nickell and Richard Layard (1999). "Labor market and Economic performance". In Hanbook of Labor. eds O. Ashenfelter and D. Card. Edition Nord-Holand.

25. Ronald Oaxaca. "Male-Female Wage Differentials in Urban Labor Markets". International Economic Review 14 (October 1973): 693-709.

26. Ronald Oaxaca and Michael Ransom. "Calculation of Approximate Variance for the Wage Decomposition Differential". Journal of Economic and Social Measurement 24 (1998): 55-61.

27. Barry Reilly. "The gender pay gap in Russia during the transition, 1992-1996". Discussion papers in Economics 04/97. University of Sussex, England, 1997.

28. Patricia Rice. (1999). "Gender Earnings Differentials: The European Experience, Policy Research Report on Gender and development". Working Paper Series 8. The World Bank, 1999.

29. R.E. Rowthorn. "Centralisation, employment and wage dispersion". Economic Journal 102 (May 1992): 506-523.

30. Jill Rubery, Mark Smith, Colette Fagan and Damian Grimshaw. "Women and European Employment". In Gender Work \& Organization. eds. David Knights and Deborah Kerfoot. Routledge: London, 1998.

31. Peter Schmidt and Robert P. Strauss. "The Prediction of Occupation Using Multiple ogit Models". International Economic Review 16 (June 1975): 471-486.

32. Wing Suen. "Decomposing Wage Residuals: Unmeasured Skill or Statistical Artifact?". Journal of Labor Economics 15 (July 1997): 555-566.

33. Franz Traxler, Sabine Blaschke and Bernhard Kittel. "National Labour Relations in Internationalised Markets: A Comparative Study of Institutions, Change, and Performance". Oxford University Press, 2001 
34. Eileen Trzcinski. "Employers' Parental Leave Policies: Does the Labor Market Provide Parental Leave?". In Parental leave and Child Care: Setting a Research and Policy Agenda. eds Janet Shibley Hyde and Marilyn J. Essex. Philadelphia, PA: Temple University Press, 1991.

35. Gillian Whitehouse. "Legislation and Labour Market Gender Inequality: An Analysis of OECD Countries". Work, Employment and Society 6 (1992): 65-88. 


\section{Appendix: Mean (Standard Deviation) of Selected Variables \& Results of the Wage Equations}

\section{Belgium}

\begin{tabular}{|c|c|c|c|c|c|c|}
\hline \multirow[b]{3}{*}{$\begin{array}{l}\text { Ln of the gross hourly wage in } \\
\text { BEF }(1 \mathrm{ECU}=37.64 \mathrm{BEF})^{1} \text {. }\end{array}$} & \multicolumn{2}{|c|}{ Aggregate } & \multicolumn{2}{|c|}{ Women } & \multicolumn{2}{|c|}{ Men } \\
\hline & Mean (st.d.) $)^{2}$ & Reg. coeffic. ${ }^{3}$ & Mean (st.d.) ${ }^{2}$ & Reg. coeffic. ${ }^{3}$ & Mean (st.d.) $^{2}$ & Reg. coeffic. ${ }^{3}$ \\
\hline & $6.245(0.4)$ & & $6.103(0.4)$ & & $6.304(0.4)$ & \\
\hline \multicolumn{7}{|l|}{ Explanatory variables: } \\
\hline Intercept & & $3.995 * *(129.4)$ & & $4.140 * *(106.7)$ & & $3.772 * *(73.9)$ \\
\hline Education (number of years of & $11.3(2.9))$ & $0.087 * *(220.3)$ & $11.5(2.7)$ & $0.081 * *(100.17)$ & $11.2(2.9)$ & $0.089 * *(196.3)$ \\
\hline schooling) & & Reference & & Reference & & Reference \\
\hline \multicolumn{7}{|l|}{$\operatorname{Sex}$} \\
\hline Male & 70.8 & Reference & & & & \\
\hline Female & 29.2 & $-0.125^{* *}(-52.9)$ & & & & \\
\hline \multicolumn{7}{|c|}{$\begin{array}{l}\text { Prior potential experience (experience accumulated } \\
\text { on the labour market before the last job. years) }\end{array}$} \\
\hline Simple & $9.6(8.9)$ & $0.026^{* *}(69.9)$ & $9.1(8.6)$ & $0.023 * *(34.7)$ & $9.8(8.2)$ & $0.028 * *(60.8)$ \\
\hline Squared $/ 10^{2}$ & & $-0.044 * *(-39.4)$ & & $-0.043 * *(-22.1)$ & & $-0.046 * *(-33.32)$ \\
\hline \multicolumn{7}{|l|}{ Seniority in the company (years) } \\
\hline Simple & $10.4(9.5)$ & $0.027 * *(73.85)$ & $8.8(8.7)$ & $0.026^{* *}(37.6)$ & $11.0(9.7)$ & $0.027 * *(62.3)$ \\
\hline Squared $/ 10^{2}$ & & $-0.023 * *(-20.3)$ & & $-0.021 * *(-8.7)$ & & $-0.0 .23 * *(-17.3)$ \\
\hline $\begin{array}{l}\text { Dummy }=1 \text { if the ind. has no } \\
\text { seniority }\end{array}$ & 0.0 & $-0.152 * *(-12.5)$ & 0.0 & $-0.164 * *(-8.7)$ & 0.0 & $-0.146 * *(-9.2)$ \\
\hline $\begin{array}{l}\text { Hours (ln of number of hours } \\
\text { paid. including overtime paid) } \\
\text { Type of contract }\end{array}$ & $7.5(0.3)$ & $0.079 * *(19.8)$ & 7.4() & $0.058 * *(11.2)$ & $7.6(0.2)$ & $0.104 * *(15.5)$ \\
\hline Permanent employment contract & 97.1 & Reference & 95.6 & Reference & 97.7 & Reference \\
\hline Fixed-term employment contract & 2.9 & $-0.08 * *(-12.9)$ & 4.4 & $-0.108 * *(-11.6)$ & 2.3 & $-0.057 *(-6.9)$ \\
\hline Overtime paid: Yes & 8.0 & $-0.027 * *(-7.3)$ & 2.8 & $0.023 * *(2.08)$ & 10.2 & $-0.035 *(-8.6)$ \\
\hline $\begin{array}{l}\text { Size of the establishment (ln of } \\
\text { number of workers) }\end{array}$ & $5.0(1.68)$ & $0.059 * *(93.1)$ & $4.8(1.5)$ & $0.057 * *(45.1)$ & $5.1(1.7)$ & $0.060 * *(81.83)$ \\
\hline $\mathrm{R}^{2}$ & & 0.520 & & 0.479 & & 0.505 \\
\hline F-test & & $8041.0 * *$ & & $2066.1 * *$ & & $6023.8 * *$ \\
\hline Number of observations & & 81608 & & 22485 & & 59123 \\
\hline
\end{tabular}

${ }^{1}$ It includes overtime paid and bonuses for shift work. night work and or weekend work and bonuses (i.e. irregular payments which do not occur during each pay period. such as pay for holiday. $13^{\text {th }}$ month. arrears. advances. travelling expenses. etc. ${ }^{2}$ The descriptive statistics refer to the weighted sample. ${ }^{3}$ Model estimated by ordinary least squares. T-statistics between brackets. */** statistically significant at the 5 and $1 \%$ level. 


\section{Denmark}

\begin{tabular}{|c|c|c|c|c|c|c|}
\hline \multirow[b]{3}{*}{$\begin{array}{l}\text { Ln of the gross hourly wage in } \\
\text { DKK }(1 \mathrm{ECU}=7.10 \mathrm{DKK})^{1}\end{array}$} & \multicolumn{2}{|c|}{ Aggregate } & \multicolumn{2}{|c|}{ Women } & \multicolumn{2}{|c|}{ Men } \\
\hline & Mean (st.d.) $)^{2}$ & Reg. coeffic. $^{3}$ & Mean (st.d.) ${ }^{2}$ & Reg. coeffic. ${ }^{3}$ & Mean (st.d.) ${ }^{2}$ & Reg. coeffic. $^{3}$ \\
\hline & $4.907(0.3)$ & & $4.781(0.3)$ & & $4.970(0.3)$ & \\
\hline \multicolumn{7}{|l|}{ Explanatory variables: } \\
\hline Intercept & & $5.498 * *(832.1)$ & & $0.049 * *(169.8)$ & & $5.492 * *(614.5)$ \\
\hline $\begin{array}{l}\text { Education (number of years of } \\
\text { schooling) }\end{array}$ & $11.5(2.42)$ & $0.058(320.0)$ & $11.2(2.3)$ & $0.049(169.8)$ & $11.6(2.5)$ & $0.060(263.3)$ \\
\hline \multicolumn{7}{|l|}{$\operatorname{Sex}$} \\
\hline Male & 66.8 & Reference & & & & \\
\hline Female & 33.2 & $-0.177 * *(-205.4)$ & & & & \\
\hline \multicolumn{7}{|c|}{$\begin{array}{l}\text { Prior potential experience (experience accumulated } \\
\text { on the labour market before the last job. years) }\end{array}$} \\
\hline Simple & $13.8(10.4)$ & $0.017 * *(139.5)$ & $13.9(10.6)$ & $0.015^{* *}(83.2)$ & $13.8(10.3)$ & $0.018 * *(110.5)$ \\
\hline Squared $/ 10^{2}$ & & $-0.028 * *(-83.4)$ & & $-0.026 * *(-52.5)$ & & $-0.029 * *(-65.2)$ \\
\hline \multicolumn{7}{|l|}{ Seniority in the company (years) } \\
\hline Simple & $6.4(7.8)$ & $0.010 * *(65.9)$ & $5.7(7.1)$ & $0.003 * *(13.0)$ & $6.8(8.1)$ & $0.012 * *(65.5)$ \\
\hline Squared $/ 10^{2}$ & & $-0.004 * *(-7.5)$ & & $0.014 * *(14.5)$ & & $-0.011 * *(-16.8)$ \\
\hline $\begin{array}{l}\text { Dummy }=1 \text { if the ind. has no } \\
\text { seniority }\end{array}$ & $0.0(0.1)$ & $-0.024 * *(-3.8)$ & $0.0(0.1)$ & $-0.002(-0.20)$ & $0.0(0.1)$ & $-0.037 * *(-4.35)$ \\
\hline $\begin{array}{l}\text { Hours (ln of number of hours } \\
\text { paid. including overtime paid) } \\
\text { Type of contract }\end{array}$ & $7.3(0.5)$ & $-0.193 * *(-216.9)$ & $7.9(0.5)$ & $-0.182 * *(-147.6)$ & $7.4(0.5)$ & $-0.200 * *(-164.2)$ \\
\hline Permanent employment contract & 98.1 & Reference & 97.8 & Reference & 98.3 & Reference \\
\hline Fixed-term employment contract & 1.9 & $-0.045^{* *}(-15.2)$ & 2.2 & $-0.044 * *(583.7)$ & 1.7 & $-0.050 * *(-12.3)$ \\
\hline Overtime paid: Yes & 24.9 & $-0.055^{* *}(-57.4)$ & 19.0 & $0.014 * *(8.95)$ & 27.9 & $-0.081 * *(-66.3)$ \\
\hline $\begin{array}{l}\text { Size of the establishment ( } \ln \text { of } \\
\text { number of workers) }\end{array}$ & $5.3(1.9)$ & $0.004 * *(19.0)$ & $5.4(2.0)$ & $-0.000(-1.34)$ & $5.2(1.8)$ & $0.006^{* *}(20.4)$ \\
\hline $\mathrm{R}^{2}$ & & 0.291 & & 0.201 & & 0.262 \\
\hline F-test & & $19596.5^{* *}$ & & $4946.7 * *$ & & $11703.9^{* *}$ \\
\hline Number of observations & & 525296 & & 196325 & & 328971 \\
\hline
\end{tabular}

${ }^{1}$ It includes overtime paid and bonuses for shift work. night work and or weekend work and bonuses (i.e. irregular payments which do not occur during each pay period. such as pay for holiday. $13^{\text {th }}$ month. arrears. advances. travelling expenses. etc. ${ }^{2}$ The descriptive statistics refer to the weighted sample. ${ }^{3}$ Model estimated by ordinary least squares. T-statistics between brackets. $* / * *$ statistically significant at the 5 and $1 \%$ level. 
3. Italy

\begin{tabular}{|c|c|c|c|c|c|c|}
\hline \multirow[b]{3}{*}{$\begin{array}{l}\text { Ln of the gross hourly wage in } \\
\times 1000 \text { ITL }(1 \text { ECU }=2031.98 \\
\text { ITL })^{1} \text {. }\end{array}$} & \multicolumn{2}{|c|}{ Aggregate } & \multicolumn{2}{|c|}{ Women } & \multicolumn{2}{|c|}{ Men } \\
\hline & Mean (st.d.) ${ }^{2}$ & Reg. coeffic. $^{3}$ & Mean (st.d.) $)^{2}$ & Reg. coeffic. $^{3}$ & Mean (st.d.) ${ }^{2}$ & Reg. coeffic. $^{3}$ \\
\hline & $2.815(0.4)$ & & $2.641(0.4)$ & & $2.886(0.4)$ & \\
\hline \multicolumn{7}{|l|}{ Explanatory variables: } \\
\hline Intercept & & $2.691 * *(44.8)$ & & $1.971 * *(25.8)$ & & $3.947 * *(41.1)$ \\
\hline $\begin{array}{l}\text { Education (number of years of } \\
\text { schooling) }\end{array}$ & $9.6(3.2)$ & $0.067 * *(183.3)$ & $9.7(3.1)$ & $0.059 * *(83.4)$ & $9.6(3.3)$ & $0.069 * *(163.8)$ \\
\hline \multicolumn{7}{|l|}{$\operatorname{Sex}$} \\
\hline Male & 71.0 & Reference & & & & \\
\hline Female & 29.0 & $-0.184 * *(-78.7)$ & & & & \\
\hline \multicolumn{7}{|c|}{$\begin{array}{l}\text { Prior potential experience (experience accumulated } \\
\text { on the labour market before the last job. years) }\end{array}$} \\
\hline Simple & $12.1(9.7)$ & $0.017 * *(58.5)$ & $10.6(9.5)$ & $0.010 * *(18.6)$ & $12.7(9.7)$ & $0.020 * *(59.9)$ \\
\hline Squared $/ 10^{2}$ & & $-0.019 * *(-28.1)$ & & $-0.012 * *(-8.1)$ & & $-0.025 * *(-31.4)$ \\
\hline \multicolumn{7}{|l|}{ Seniority in the company (years) } \\
\hline Simple & $10.5(8.8)$ & $0.027 * *(70.5)$ & $9.3(8.4)$ & $0.027 * *(37.0)$ & $10.9(9.0)$ & $0.027 * *(61.0)$ \\
\hline Squared $/ 10^{2}$ & & $-0.022 * *(-17.3)$ & & $-0.029 * *(-12.4)$ & & $-0.020 * *(-13.6)$ \\
\hline $\begin{array}{l}\text { Dummy }=1 \text { if the ind. has no } \\
\text { seniority }\end{array}$ & $0.0(0.1)$ & $0.145^{* *}(8.06)$ & $0.0(0.1)$ & $0.219 * *(6.1)$ & $0.0(0.1)$ & $0.136^{* *}(6.55)$ \\
\hline $\begin{array}{l}\text { Hours (ln of number of hours } \\
\text { paid. including overtime paid) } \\
\text { Type of contract }\end{array}$ & $7.6(0.1)$ & $-0.144 * *(-18.5)$ & $7.6(0.2)$ & $-0.062 * *(-6.3)$ & $7.6(0.1)$ & $-0.314 * *(-25.0)$ \\
\hline Permanent employment contract & 97.4 & Reference & 96.2 & Reference & 97.9 & Reference \\
\hline Fixed-term employment contract & 2.6 & $-0.069 * *(-10.5)$ & 3.8 & $-0.040 * *(-3.9)$ & 2.1 & $-0.103 * *(-12.2)$ \\
\hline Overtime paid: Yes & 38.5 & $0.025^{* *}(11.0)$ & 28.2 & $0.072 * *(16.9)$ & 42.6 & $0.025 * *(8.7)$ \\
\hline $\begin{array}{l}\text { Size of the establishment ( } \ln \text { of } \\
\text { number of workers) }\end{array}$ & $4.6(1.9)$ & $0.050 * *(85.6)$ & $4.3(1.8)$ & $0.060 * *(53.9)$ & $4.7(1.9)$ & $0.045^{* *}(66.7)$ \\
\hline $\mathrm{R}^{2}$ & & 0.494 & & 0.441 & & 0.473 \\
\hline F-test & & $8290.56 * *$ & & $1834.33^{* *}$ & & $6281.61 * *$ \\
\hline Number of observations & & 93289 & & 23273 & & 70016 \\
\hline
\end{tabular}




\section{Ireland}

\begin{tabular}{|c|c|c|c|c|c|c|}
\hline \multirow[b]{3}{*}{$\begin{array}{l}\text { Ln of the gross hourly wage in } \\
\text { IR£ }(1 \text { ECU }=\operatorname{IR} £ 0.80)^{1} .\end{array}$} & \multicolumn{2}{|c|}{ Aggregate } & \multicolumn{2}{|c|}{ Women } & \multicolumn{2}{|c|}{ Men } \\
\hline & Mean (st.d.) ${ }^{2}$ & Reg. coeffic. ${ }^{3}$ & Mean (st.d.) ${ }^{2}$ & Reg. coeffic. ${ }^{3}$ & Mean (st.d.) ${ }^{2}$ & Reg. coeffic. ${ }^{3}$ \\
\hline & $2.018(0.6)$ & & $1.804(0.5)$ & & $2.163(0.6)$ & \\
\hline \multicolumn{7}{|l|}{ Explanatory variables: } \\
\hline Intercept & & $-1.204 * *(-23.5)$ & & $-1.279 * *(-20.1)$ & & $-1.115 * *(-13.8)$ \\
\hline Education (number of years of & $12.815(1.9)$ & $0.124 * *(98.3)$ & $12.9(1.8)$ & $0.114 * *(56.4)$ & $12.8(2.1)$ & $0.127 * *(78.78)$ \\
\hline schooling) & & Reference & & Reference & & Reference \\
\hline \multicolumn{7}{|l|}{$\operatorname{Sex}$} \\
\hline Male & 59.6 & Reference & & & & \\
\hline Female & 40.4 & $-0.22 * *(-46.2)$ & & & & \\
\hline \multicolumn{7}{|c|}{$\begin{array}{l}\text { Prior potential experience (experience accumulated } \\
\text { on the labour market before the last job. years) }\end{array}$} \\
\hline Simple & $7.5(8.3)$ & $0.033 * *(44.8)$ & $6.9(8.4)$ & $0.028^{* *}(24.8)$ & $7.7(8.2)$ & $0.038 * *(38.5)$ \\
\hline Squared $/ 10^{2}$ & & $-0.071 * *(-29.6)$ & & $-0.070 * *(-18.2)$ & & $-0.075^{* *}(-24.1)$ \\
\hline \multicolumn{7}{|l|}{ Seniority in the company (years) } \\
\hline Simple & $9.3(8.9)$ & $0.052 * *(66.2)$ & $7.1(7.0)$ & $0.053^{* *}(37.8)$ & $10.8(9.7)$ & $0.052 * *(51.8)$ \\
\hline Squared $/ 10^{2}$ & & $-0.072 * *(-29.8)$ & & $-0.082 * *(-16.0)$ & & $-0.070 * *(-23.7)$ \\
\hline $\begin{array}{l}\text { Dummy=1 if the ind. has no } \\
\text { seniority }\end{array}$ & $0.1(0.3)$ & $-0.135^{* *}(-14.8)$ & $0.1(0.3)$ & $-0.113 * *(-9.1)$ & $0.1(0.3)$ & $-0.161 * *(-12.2)$ \\
\hline $\begin{array}{l}\text { Hours (ln of number of hours } \\
\text { paid. including overtime paid) } \\
\text { Type of contract }\end{array}$ & $6.1(0.3)$ & $0.154 * *(19.3)$ & $6.0(0.4)$ & $0.160^{* *}(16.4)$ & $6.1(0.3)$ & $0.126^{* *}(9.7)$ \\
\hline Permanent employment contract & 95.8 & Reference & 95.6 & Reference & 96.0 & Reference \\
\hline Fixed-term employment contract & 4.2 & $-0.007(-0.6)$ & 4.4 & $0.058^{* *}(3.6)$ & 4.0 & $-0.052 * *(-3.4)$ \\
\hline Overtime paid: Yes & 33.2 & $-0.045^{* *}(-8.6)$ & 23.2 & $0.022 * *(2.75)$ & 39.9 & $-0.076^{* *}(-10.9)$ \\
\hline $\begin{array}{l}\text { Size of the establishment }(\ln \text { of } \\
\text { number of workers) }\end{array}$ & $5.8(1.8)$ & $0.048 * *(37.8)$ & $6.0(1.8)$ & $0.041 * *(22.6)$ & $5.7(1.8)$ & $0.054 * *(31.1)$ \\
\hline $\mathrm{R}^{2}$ & & 0.485 & & 0.421 & & 0.449 \\
\hline F-test & & $3080.48^{* *}$ & & $999.02 * *$ & & $1810.73^{* *}$ \\
\hline Number of observations & & 35941 & & 13713 & & 22228 \\
\hline
\end{tabular}




\section{Spain}

\begin{tabular}{|c|c|c|c|c|c|c|}
\hline \multirow[b]{3}{*}{$\begin{array}{l}\text { Ln of the gross hourly wage in } \\
\text { PTS }(1 \mathrm{ECU}=155.27 \mathrm{pts})^{1} \text {. }\end{array}$} & \multicolumn{2}{|c|}{ Aggregate } & \multicolumn{2}{|c|}{ Women } & \multicolumn{2}{|c|}{ Men } \\
\hline & Mean (st.d.) $)^{2}$ & Reg. coeffic. $^{3}$ & $\operatorname{Mean}(\text { st.d. })^{2}$ & Reg. coeffic. ${ }^{3}$ & Mean (st.d.) ${ }^{2}$ & Reg. coeffic. ${ }^{3}$ \\
\hline & $7.093(0.5)$ & & $6.863(0.5)$ & & $7.167(0.5)$ & \\
\hline \multicolumn{7}{|l|}{ Explanatory variables: } \\
\hline Intercept & & $6.131 * *(139.3)$ & & $5.807 * *(103.1)$ & & $6.517 * *(93.1)$ \\
\hline $\begin{array}{l}\text { Education (number of years of } \\
\text { schooling) }\end{array}$ & $9.1(3.0)$ & $0.083 * *(222.4)$ & $9.5(2.9)$ & $0.083 * *(106.1)$ & $9.0(3.1)$ & $0.083 * *(195.5)$ \\
\hline \multicolumn{7}{|l|}{$\operatorname{Sex}$} \\
\hline Male & 75.7 & Reference & & & & \\
\hline Female & 24.3 & $-0.239 * *(-103.4)$ & & & & \\
\hline \multicolumn{7}{|c|}{$\begin{array}{l}\text { Prior potential experience (experience accumulated } \\
\text { on the labour market before the last job. years) }\end{array}$} \\
\hline Simple & $13.0(9.7)$ & $0.021 * *(65.5)$ & $10.9(9.3)$ & $0.025 * *(37.1)$ & $13.6(9.8)$ & $0.022 * *(56.9)$ \\
\hline Squared $/ 10^{2}$ & & $-0.028 * *(-34.6)$ & & $-0.045 * *(-25.7)$ & & $-0.026 * *(-28.3)$ \\
\hline \multicolumn{7}{|l|}{ Seniority in the company (years) } \\
\hline Simple & $10.4(10.0)$ & $0.030 * *(74.5)$ & $8.3(8.6)$ & $0.037 * *(40.9)$ & $11.1(10.1)$ & $0.276^{* *}(59.6)$ \\
\hline Squared $/ 10^{2}$ & & $-0.031 * *(-26.6)$ & & $-0.039 * *(-13.7)$ & & $-0.026 * *(-19.7)$ \\
\hline $\begin{array}{l}\text { Dummy=1 if the ind. has no } \\
\text { seniority }\end{array}$ & $0.0(0.0)$ & $0.063(0.18)$ & $0.0(0.0)$ & () & $0.0(0.0)$ & $0.072(0.20)$ \\
\hline $\begin{array}{l}\text { Hours (ln of number of hours } \\
\text { paid. including overtime paid) } \\
\text { Type of contract }\end{array}$ & $7.5(0.2)$ & $-0.055 * *(-9.64)$ & $7.5(0.3)$ & $-0.048 * *(-6.5)$ & $7.6(0.1)$ & $-0.106 * *(-11.5)$ \\
\hline Permanent employment contract & 73.1 & Reference & 68.5 & Reference & 74.5 & Reference \\
\hline Fixed-term employment contract & 26.9 & $-0.184 * *(-59.9)$ & $31.5(0.5)$ & $-0.138 * *(-24.2)$ & 25.5 & $-0.205 * *(-56.1)$ \\
\hline Overtime paid: Yes & 9.5 & $0.102 * *(31.0)$ & 4.8 & $0.130 * *(14.8)$ & 11.0 & $0.099 * *(27.6)$ \\
\hline $\begin{array}{l}\text { Size of the establishment (ln of } \\
\text { number of workers) }\end{array}$ & $4.6(1.8)$ & $0.059 * *(100.0)$ & $4.6(1.7)$ & $0.052 * *(45.1)$ & $4.5(1.8)$ & $0.061 * *(89.6)$ \\
\hline $\mathrm{R}^{2}$ & & 0.498 & & 0.453 & & 0.474 \\
\hline F-test & & $14796.7 * *$ & & $3494.9 * *$ & & $11358.9^{* *}$ \\
\hline Number of observations & & 164240 & & 37901 & & 126339 \\
\hline
\end{tabular}

